\title{
Protein-TiO2: A Functional Hybrid Composite with Diversified Applications
}

\author{
Luis Miguel Anaya-Esparza 1,2® , Zuamí Villagrán-de la Mora $^{3}{ }^{\circledR}$, Noé Rodríguez-Barajas ${ }^{2}$,

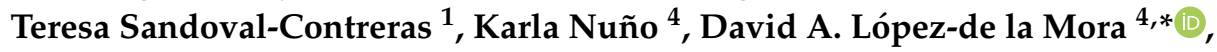 \\ Alejandro Pérez-Larios ${ }^{2, *}$ and Efigenia Montalvo-González ${ }^{1, *}$ (D) \\ 1 Laboratorio Integral de Investigación en Alimentos, Tecnológico Nacional de México-Instituto \\ Tecnológico de Tepic, Av. Tecnológico 2595 Fracc, Lagos del Country, Tepic 63175, Mexico; \\ lumianayaes@ittepic.edu.mx (L.M.A.-E.); tesysval@gmail.com (T.S.-C.) \\ 2 Laboratorio de Materiales, Agua y Energía, División de Ciencias Agropecuarias e Ingenierías, \\ Centro Universitario de los Altos, Universidad de Guadalajara, Av. Rafael Casillas Aceves 1200, \\ Tepatitlán de Morelos 47600, Mexico; noe.rbarajas@academicos.udg.mx \\ 3 División de Ciencias Biomédicas, Centro Universitario de los Altos, Universidad de Guadalajara, \\ Av. Rafael Casillas Aceves 1200, Tepatitlán de Morelos 47600, Mexico; blanca.villagran@academicos.udg.mx \\ 4 División de Ciencias de la Salud, Centro Universitario de Tonalá, Universidad de Guadalajara, \\ Av. 555 Ejido San José Tateposco, Nuevo Perif. Ote., Tonalá 475425, Mexico; \\ karlajanette.nuno@cutonala.udg.mx \\ * Correspondence: david.ldelamora@academicos.udg.mx (D.A.L.-d.1.M.); alarios@cualtos.udg.mx (A.P.-L.); \\ emontalvo@ittepic.edu.mx (E.M.-G.)
}

Received: 4 November 2020; Accepted: 2 December 2020; Published: 7 December 2020

check for updates

\begin{abstract}
Functionalization of protein-based materials by incorporation of organic and inorganic compounds has emerged as an active research area due to their improved properties and diversified applications. The present review provides an overview of the functionalization of protein-based materials by incorporating $\mathrm{TiO}_{2}$ nanoparticles. Their effects on technological (mechanical, thermal, adsorptive, gas-barrier, and water-related) and functional (antimicrobial, photodegradation, ultraviolet (UV)-protective, wound-healing, and biocompatibility) properties are also discussed. In general, protein- $\mathrm{TiO}_{2}$ hybrid materials are biodegradable and exhibit improved tensile strength, elasticity, thermal stability, oxygen and water resistance in a $\mathrm{TiO}_{2}$ concentration-dependent response. Nonetheless, they showed enhanced antimicrobial and UV-protective effects with good biocompatibility on different cell lines. The main applications of protein- $\mathrm{TiO}_{2}$ are focused on the development of eco-friendly and active packaging materials, biomedical (tissue engineering, bone regeneration, biosensors, implantable human motion devices, and wound-healing membranes), food preservation (meat, fruits, and fish oil), pharmaceutical (empty capsule shell), environmental remediation (removal and degradation of diverse water pollutants), anti-corrosion, and textiles. According to the evidence, protein- $\mathrm{TiO}_{2}$ hybrid composites exhibited potential applications; however, standardized protocols for their preparation are needed for industrial-scale implementation.
\end{abstract}

Keywords: proteins; titanium dioxide; functionalization; hybrid composites

\section{Introduction}

Nowadays, the development of eco-friendly materials with advanced characteristics and diverse applications is an active research area [1,2]. Hybrid compounds are composites that consist of combining inorganic-inorganic (e.g., $\mathrm{TiO}_{2}-\mathrm{Ag}$ ), organic-organic (e.g., wheat gluten-cellulose), and organic-inorganic (e.g., collagen- $\mathrm{TiO}_{2}$ ) [3-5], and they can be synthesized by spin and dip coating, slot-casting, electrochemical self-assembly, and chemical vapor, atomic or molecular layer 
deposition methods [6]. In general, hybridization or functionalization of organic compounds by incorporating inorganic compounds is a strategy that enables the attainment of hybrid materials with beneficial properties and new functionalities [6,7]. Recently, titanium dioxide $\left(\mathrm{TiO}_{2}\right)$ has been used as a reinforcement agent to develop organic-inorganic hybrid materials with improved physicochemical, mechanical, UV- and gas-barrier, water resistance, and antimicrobial properties [1,3,8-11].

$\mathrm{TiO}_{2}$ is an amphoteric, inert, non-toxic, biocompatible metal oxide that exhibited thermal and chemical stability for diverse applications with a relatively low cost of production [12]. The wide use of $\mathrm{TiO}_{2}$ is to support its photocatalytic, adsorptive, UV-blocking, and antimicrobial properties [13-15]. It has been employed for environmental remediation in dye removal from aqueous media [16]. Moreover, $\mathrm{TiO}_{2}$ is the main source of white pigments for food, pharmaceutical, and cosmetic applications in compliance with the recommended safe dosage [17-19]. Currently, there is a great interest in combining protein-based materials with inorganic compounds like titanium dioxide to fabricate protein- $\mathrm{TiO}_{2}$ hybrid structures with improved physical and chemical properties, which open new opportunities and applications [1].

In the last decade, protein- $\mathrm{TiO}_{2}$ hybrid composites and their potential applications have been explored [4,20-24]. Wang et al. [23] developed a soy protein isolate film combined with $\mathrm{TiO}_{2}$ with antimicrobial properties against Escherichia coli and Staphylococcus aureus. Similar trends were reported when a marine algae protein-based film functionalized with $\mathrm{TiO}_{2}$ was used [25]. Fathi et al. [16] informed that the sesame protein- $\mathrm{TiO}_{2}$ hybrid film showed photocatalytic degradation of the methylene blue dye under UV-light radiation. Qingyan et al. [26] made gelatin film reinforced with $\mathrm{TiO}_{2}$ with improved mechanical and UV-protective properties. Fan et al. [27] fabricated a collagen-chitosan- $\mathrm{TiO}_{2}$ porous scaffold for wound-healing purposes. Meanwhile, He et al. [27] developed an active packaging with marine alga (Gracilaria lemaneiformis) protein isolate and $\mathrm{TiO}_{2}$ for cherry tomatoes preservation, while a whey protein- $\mathrm{TiO}_{2}$ hybrid film was used to prolong the shelf life of chilled and lamb meats [28,29]. Furthermore, the incorporation of $\mathrm{TiO}_{2}$ in diverse protein-based materials (collagen, gelatin, soy, hey, marine alga, kefiran, zein, sesame, sodium caseinate, and wheat gluten) had a positive impact on the technological (mechanical, water resistance, and gas-barrier) and functional (antimicrobial and UV-protective) properties, which exhibited potential uses for various applications $[16,17,20,24,25,30,31]$.

This review summarizes the advantages and limitations of protein-based material functionalization by adding $\mathrm{TiO}_{2}$ nanoparticles, offers and provides an overview of their photocatalytic and antimicrobial properties, environmental remediation, potential food and non-food packaging, pharmaceutical, cosmetics, textile, and biomedical applications.

\section{Proteins: Applications and Limitations}

Proteins are biological molecules composed of $\alpha$-amino acids connected by peptide bonds, which can be obtained from plant-derived or animal origins [32]. For example, zein and gluten are cereal proteins [4,33], meanwhile, other proteins can be obtained from legumes such as soy [19]. Collagen and gelatin are extracted from meat, fish, and poultry by-products [1,34], whereas whey protein is a by-product of dairy manufacturing [29]. They exhibited interesting technological and functional properties for diversified applications, associated with their composition and structure [2]. Moreover, they are non-toxic, abundant, readily available, biodegradable, low-cost, and biocompatible to combine with enzymes, microorganisms, and organic and inorganic compounds [6,32,35]. Most of the applications described in the literature for protein-based materials are focused on developing packaging materials for food and non-food purposes, or biomedical applications such as wound-healing materials, as shown in Table 1. 
Table 1. Potential applications of some protein-based materials.

\begin{tabular}{ccc}
\hline Protein Source & Application & Ref. \\
\hline Yellow pea protein isolate & Food and non-food packaging & {$[36]$} \\
Whey protein & Food and non-food packaging & {$[37]$} \\
Corn zein & Food and non-food packaging & {$[38]$} \\
Soy protein isolate & Food and non-food packaging & {$[39]$} \\
Rice bran & Food and non-food packaging & {$[40]$} \\
Wheat gluten & Food and non-food packaging & {$[41]$} \\
Gelatin & Food and non-food packaging & {$[42]$} \\
Gelatin & Biomedical & {$[43]$} \\
Keratin & Biomedical & {$[44]$} \\
\hline
\end{tabular}

Acquah et al. [36] fabricated a yellow pea (Pisum sativum) protein-based film with potential food and non-food packaging applications. It exhibited moderate water solubility $(36.5 \%)$, good mechanical properties (elongation of $65 \%$, a tensile strength of $0.65 \mathrm{MPa}$, and elastic modulus of $6.65 \mathrm{MPa}$ ), as well as good thermal properties (glass transition of $95.5^{\circ} \mathrm{C}$ ), but high moisture uptake $(82 \%)$ due to its hydrophilic nature (contact angle of $60^{\circ}$ ), affecting its quality as a packaging material. Agudelo-Cuartas et al. [37] mentioned that whey protein-based films showed great potential for packaging purposes (good mechanical properties); however, their high-water solubility (59\%) and water vapor permeability $\left(1.4 \times 10^{-10} \mathrm{~g} \cdot \mathrm{m}^{-1} \cdot \mathrm{s}^{-1} \cdot \mathrm{Pa}^{-1}\right)$ limit their uses in foods with high water content (e.g., meat). According to Guo et al. [38], the protein-based film's mechanical properties are influenced by storage conditions (temperature and relative humidity). They found that tensile strength and elongation at break of a zein film were negatively affected when relative humidity and temperature increased from $34 \%$ to $80 \%$ and from 5 to $35^{\circ} \mathrm{C}$, respectively. They argue that the available -SH groups in the protein structure decreased gradually during storage by water absorption, implying new and weak interactions.

Su et al. [39] reported that soy protein isolate film exhibited good biodegradability and gas-barrier properties against oxygen and carbon dioxide when relative humidity was low, which are suitable featuring for the development of packaging materials. Wang et al. [40] suggested that modification of protein structure by alkaline conditions could be an alternative to improve the technological properties of protein-based films. They reported that the formation of protein aggregates in a rice bran film treated at $\mathrm{pH} 11$ improved their physical, mechanical, and thermal properties, associated with an increase in the $\beta$-sheet content and non-covalent interactions, due to the modification of the protein structure.

Additionally, gelatin-based films exhibited great potential for fabricating food packaging or wound-healing materials; however, due to their hygroscopic nature, they needed to be combined with a crosslinking or plasticizer agent (organic or inorganic) to improve their water resistance and thermal stability $[42,43]$. It has been reported that keratin films are too rigid, and the addition of glycerol improved their flexibility and mechanical resistance, which are suitable for biomedical applications [44]. Similar trends were reported in a wheat gluten film by adding glycerol, but its thermal stability was improved and could be used for packaging purposes [41].

In general, protein-based films exhibited great potential applications; however, their functionality depends on their molecular characteristics, complexity, superficial charge, denaturation tendency, water resistance, and thermal stability [35]. Therefore, the incorporation of organic and inorganic materials in the protein matrix is a viable strategy to enhance their functional and technological properties $[29,32,45]$. Table 2 shows some protein-based materials functionalized with organic and inorganic compounds to form hybrid composites with potential applications. 
Table 2. Application of some functionalized protein-based materials.

\begin{tabular}{cccc}
\hline Protein Source & Functional Agent & Application & Ref. \\
\hline Gelatin & Silver-NPs & Active food packaging. & {$[46]$} \\
Gelatin & Resorcinol and silver-NPs & Active food packaging. & {$[47]$} \\
Caseinate/gelatin & Tannins & Active food packaging. & {$[48]$} \\
Sodium caseinate & ZnO-NPs and REO & Active food packaging. & {$[49]$} \\
Whey protein & Montmorillonite and citric acid & Active food packaging. & {$[50]$} \\
Whey protein & Organic acids and nisin & Active food packaging. & {$[51]$} \\
Furcellaran/whey protein & Yerba mate extracts & Active food packaging. & {$[52]$} \\
Yellow pea protein isolate & Whey protein isolate & Active food packaging. & {$[36]$} \\
Fish protein isolate & Gelatin and ZnO-NPs & Active food packaging. & {$[53]$} \\
Soy protein hydrolysate & Silica & Environmental remediation. & {$[54]$} \\
Soy protein isolate & Tragacanth, silica, and lycopene & Environmental remediation. & {$[55]$} \\
Silk fibroin & Ag NPs & Biomedical. & {$[56]$} \\
Egg white protein & Silk fibroin & Biomedical. & {$[57]$} \\
\hline
\end{tabular}

NPs: nanoparticles; ZnO: Zinc oxide; REO: rosemary essential oil.

According to the evidence, the incorporation of organic and inorganic compounds improves the technological (water and thermal resistance, mechanical, and adsorptive) and functional (antimicrobial activity and biocompatibility) properties of protein-based materials, associated with their ability to form intramolecular bonds through covalent and non-covalent interactions with the functional groups $\left(-\mathrm{NH}_{2},-\mathrm{OH},-\mathrm{COOH}\right.$, and $\left.-\mathrm{SH}\right)$ of the protein structure [6,29].

Additionally, usage of $\mathrm{TiO}_{2}$ as a functional agent to enhance the technological properties of diverse protein-based materials has been widely explored in the last years, mainly for the chemical and physical interactions between protein structure and $\mathrm{TiO}_{2}$, which could be developed using diverse methodologies.

\section{Possible Structural Interaction between $\mathrm{R}-$ Groups Amino Acid with $\mathrm{TiO}_{2}$ Nanoparticles}

A major understanding of the interactions between proteins and $\mathrm{TiO}_{2}$ surfaces will be a potential core for many applications in bio-nanotechnology [58]. Ranjan et al. [59] in silico observed that the $\mathrm{TiO}_{2}(1.09 \mathrm{~nm})$ nanoparticles bind to 13 immunological proteins (Table 3), using a docking simulation program (AutoDock 4.0), a computed atlas of surface topography of proteins (CASTp) and PyMol software (version 1.5.0.4). They observed that nano- $\mathrm{TiO}_{2}$ bound with a positively charged R-group (lysine, arginine, and histidine) and nonpolar aliphatic R-groups amino acid (proline, glycine, alanine, valine, leucine, methionine, and isoleucine) containing amino acids, most frequently with lysine and proline. On the other hand, $\mathrm{TiO}_{2}$ had less affinity with the aromatic R-group (phenylalanine, tyrosine, and tryptophan), polar uncharged R-groups (serine, threonine, cysteine, asparagine, and glutamine), and negatively charged R-group (aspartate and glutamate)-containing amino acids. According to the authors, the affinity of $\mathrm{TiO}_{2}$ with the amino acids depends on the ability to form stable hydrogen bonds, which depend on the binding and intermolecular energy of each amino acid. These interactions have been exploited to develop packaging, scaffolds, wound-healing, and dental implant materials with enhanced properties, and to remove and degrade water pollutants, among others.

Table 3. Some immunological proteins- $\mathrm{TiO}_{2}$ interaction.

\begin{tabular}{cccc}
\hline Immunological Protein & Abbreviation & Binding Energy & Intermolecular Energy \\
\hline Intercellular adhesion molecule 1 & ICAM-I & -11.63 & -12.73 \\
Mitogen-activated protein kinases & P-38 & -11.73 & -12.83 \\
The nuclear factor-kB & NF-kB & -8.29 & -9.39 \\
Cyclooxygenase 2 & COX-2 & NR & NR \\
Interleukin 8 & IL-8 & -4.04 & -5.14 \\
Placental growth factor & PIGF & -9.36 & -10.36 \\
C-X-C motif chemokine ligand 1 & CXCL-I & 1.67 & 0.57 \\
\hline
\end{tabular}


Table 3. Cont.

\begin{tabular}{cccc}
\hline Immunological Protein & Abbreviation & Binding Energy & Intermolecular Energy \\
\hline C-X-C motif chemokine ligand 3 & CXCL-3 & NR & NR \\
C-X-C motif chemokine ligand 5 & CXCL-5 & 576.34 & 575.34 \\
C-X-C motif chemokine ligand 20 & CCL-20 & -8.25 & -9.34 \\
The cluster of differentiation 35 & CD 35 & 5420 & 5420 \\
The cluster of differentiation 66b & CD 66b & NR & NR \\
Matrix metallopeptidase 9 & MMP-9 & -9.01 & -10.11 \\
\hline
\end{tabular}

Adapted from Ranjan et al. [59]. NR: No reported.

\section{Preparation of Functionalized Protein- $\mathrm{TiO}_{2}$ Materials}

The functionalization of protein-based materials through the introduction of organic (ascorbic acid, cellulose, and starch) and inorganic (metallic or metal oxide) compounds is an attractive way to fabricate protein-based hybrid materials with enhanced properties, which has seen a significant increase in the last few years [6]. The most common methods for developing functionalized protein-based materials are evaporative casting, dip-coating, layer-by-layer assembly, freeze-drying, electrospinning, and electrochemical through protein denaturation by gelation-coagulation process [6,45].

\subsection{Evaporative Casting Method}

The evaporative casting method is generally accepted and commercially used for its simplicity, flexibility, and applicability to large-scale production. It consists of preparing a viscous solution by mixing the components, casting them in a plate, and evaporating them under controlled temperature and vacuum conditions to remove the solvent solution and form film and coatings (Figure 1). In general, it is a relatively low-cost method (one-third to half of the other methods); however, its main limitations are the difficulty in achieving a uniform distribution of the reinforcement agent, the presence of air bubbles, and possible reactions between the polymeric matrix and functional agent [60].

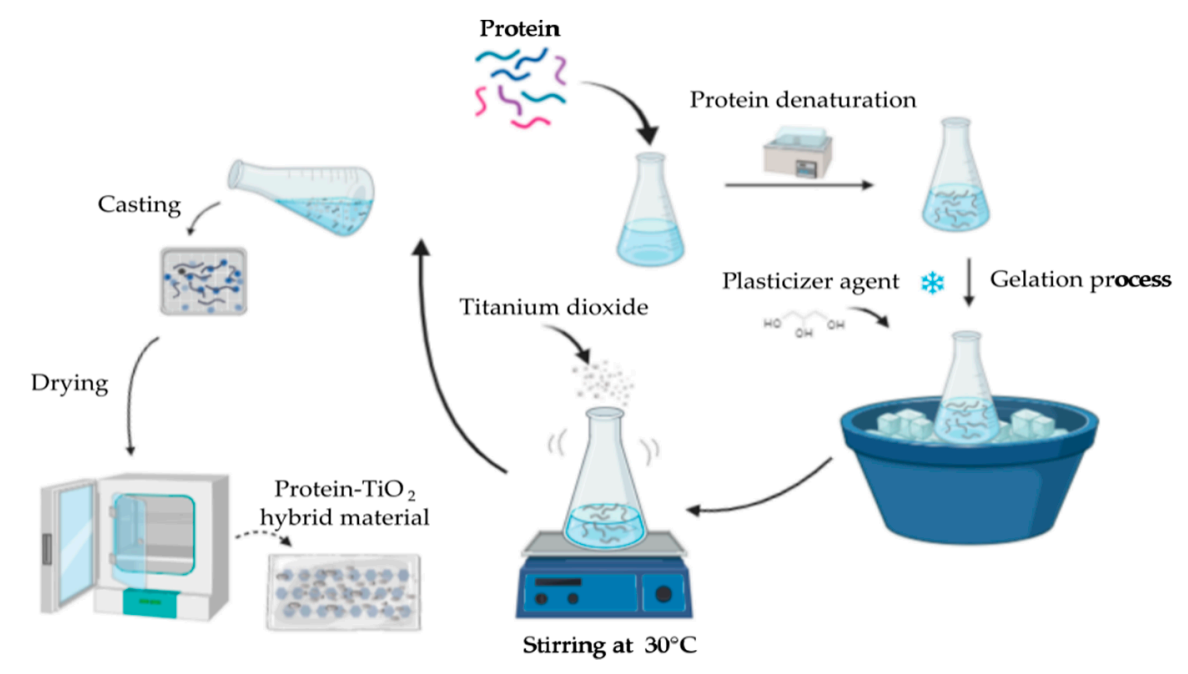

Figure 1. Schematic representation to laboratory scale of an evaporative casting method to prepare protein-based hybrid materials (adapted from Fan et al. [27], Al-Zoubi et al. [6]) (figure created with BioRender.com).

\subsection{Dip Coating Method}

Dip-coating is a technique widely used in many industrial fields to deposit onto any substrate. The process could be defined as depositing aqueous-based liquid phase coating solutions onto the surface of any substrate and is divided into five stages: immersion, start-up, deposition, drainage, 
and evaporation. It is achieved at low processing temperatures and is a low-cost method to develop thin coatings with high purity, good adhesion, high surface, and uniformity. However, this methodology requires high sintering temperatures and thermal expansion mismatch [61-63].

\subsection{Layer-by-Layer Deposition Method}

The layer-by-layer deposition is a common method for coating substrates to develop functional thin films. It is a cyclical process in which a charged material is adsorbed onto a substrate, and after washing, an oppositely charged material is adsorbed on the surface of the first layer. This constitutes a single bilayer film with a thickness generally on the order of nanometers, and the deposition process can be repeated until a multilayer film is obtained. This method offers advanced composites with exceptional properties (mechanical, electrical, optical, and biological) unavailable by other means, but this deposition process is complex, and the need for multiple dipping cycles hampers its usage in microtechnologies and electronics [64,65].

\subsection{Freeze-Drying Method}

Freeze-drying is a process that consists of removing the solvent from a frozen suspension containing mixed components. First, the gels are frozen, transforming the gel to a solid; then, sublimation of the solvent (mainly water) is then achieved at low pressure, avoiding the formation of the vapor-liquid interface. This method is widely used for aerogel preparation with highly porous and large specific surface area structures that allow rapid disintegration. However, this procedure requires sophisticated equipment compared to the evaporative casting method [66,67].

\subsection{Electospinning Method}

Electrospinning is a simple method to produce ultra-thin fibers with high surface area, highly porous structure, and small pore size. In this method, the mixed solution is pumped through a capillary conductive needle to form a droplet; under suitable conditions, solvent evaporation occurs, and the compound contracts into solid polymeric materials instead of fibers. It has the advantages of mild experimental conditions, low cost, easy operation and function, and a wide range of raw materials. The spinning process is controllable, and the parameters can be adjusted according to the different requirements in various research fields. However, electrospinning with raw materials that have a low molecular weight is difficult [68].

\subsection{Electrochemical Method}

Electrochemical methods are widely used for the preparation of thin films and coatings through anodic or cathodic techniques. Both processes are commonly used to prepare coatings by electrodeposition which include: electrophoretic process (EPD) using deposition of charged particles in a stable colloidal suspension on a conductive substrate, acting as one of the two oppositely charged electrodes in the EPD cell, and the electrolytic process (ELD), which starts from solutions of metal salts. They exhibit some advantages like low-cost, ability to coat complex shapes, speed, uniform coating thickness, rapid deposition rates, and the ability to coat complex substrates; however, it is difficult to produce crack-free coatings, it requires high sintering temperatures, and the bonding strength between coating and substrate is not strong enough $[61,69]$.

\section{Applications of Protein- $-\mathrm{TiO}_{2} \mathrm{Hybrid}$ Composites}

Protein-based materials exhibited a wide range of applications. However, most of their potential uses are limited by their poor physicochemical properties [35]. Thus, their functionalization with $\mathrm{TiO}_{2}$ is a viable alternative to improve the technological and functional properties of protein-based materials such as gelatin, wheat gluten, kefiran, zein, and soy and whey protein isolates for several applications [49] (Figure 2), as discussed below. 


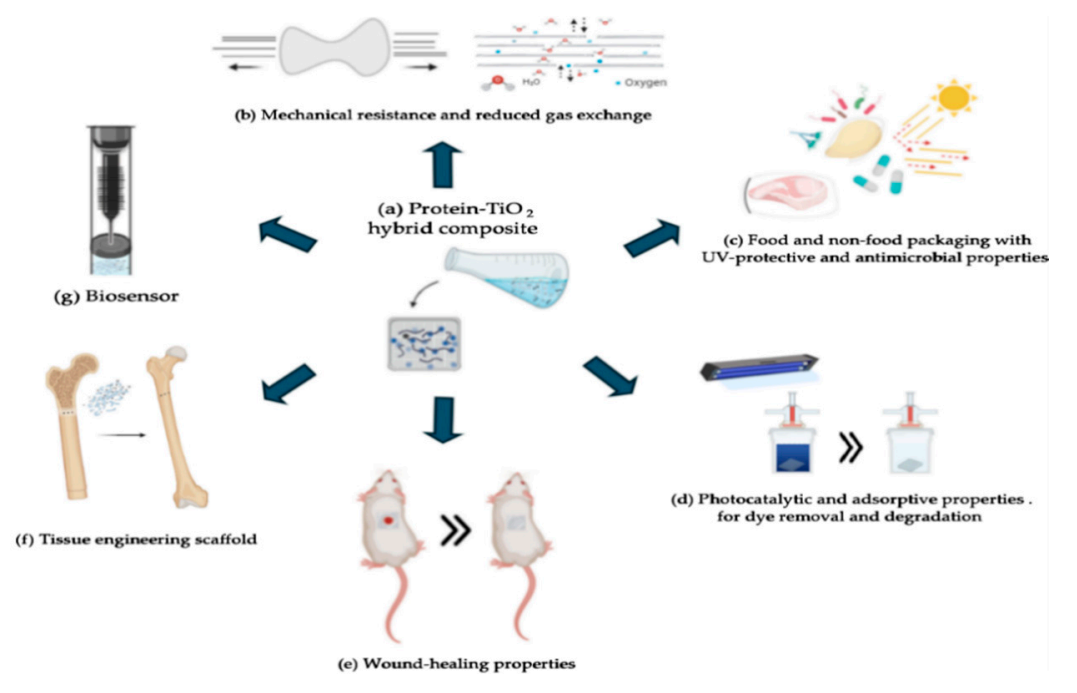

Figure 2. Protein- $\mathrm{TiO}_{2}$ hybrid composites (a) with enhanced mechanical and reduced gas exchange (b) and their applications: as food and non-food packaging with UV-protective and antimicrobial properties (c), photocatalytic activity for dye removal and degradation (d), wound-healing material (e), tissue engineering scaffolds (f), and for the development of biosensors (g) (adapted from Lin et al. [3], Fan et al. [27], Alizadeh-Sani et al. [28], Emregul et al. [70], Ferreira et al. [71]) (figure created with BioRender.com).

\subsection{Gelatin- $\mathrm{TiO}_{2}$ Hybrid Composite}

In the last years, the number of applications of gelatin-based materials has considerably increased. Gelatin is a protein obtained from the hydrolysis of collagen from mammalian sources, mainly pork and cattle. It is non-toxic, biodegradable, and biocompatible [72]. However, its main disadvantage for industrial applications (e.g., food packaging) is its hydrophilicity [73]. Therefore, the incorporation of $\mathrm{TiO}_{2}$ into the gelatin matrix is a viable strategy to improve its technological and functional properties [74]. The most common method for the preparation of gelatin- $\mathrm{TiO}_{2}$ hybrid composites is evaporative casting for films and coatings and freeze-drying for aerogels. Furthermore, the nanoparticles used are commercially available with sizes ranging from 10 to $25 \mathrm{~nm}$ in its anatase phase, in some cases in its rutile phase, using concentrations $\leq 1 \%$ in weight of total solid content, as shown in Table 4 .

Table 4. Effect of $\mathrm{TiO}_{2}$ incorporation on gelatin matrix properties.

\begin{tabular}{|c|c|c|c|c|c|}
\hline Application & Method/Presentation & * Composition & $\mathrm{TiO}_{2}$ Specifications & Relevant Results & Ref. \\
\hline $\begin{array}{l}\text { Food and } \\
\text { non-food } \\
\text { packaging }\end{array}$ & $\begin{array}{l}\text { Evaporative } \\
\text { casting/Film }\end{array}$ & $\begin{array}{c}\text { Gelatin }(4 \mathrm{~g} \\
\left.100 \mathrm{~mL}^{-1}\right), \text { glycerol } \\
(30 \% w / w)\end{array}$ & $\begin{array}{c}\text { Commercial } \\
\text { SM: Hydrothermal } \\
\left(\mathrm{TiO}_{2}\right): 0.5 \% w / w \\
\text { Size: } 25 \mathrm{~nm} \\
\text { CP: Anatase }\end{array}$ & $\begin{array}{c}\mathrm{TiO}_{2} \text { enhanced the } \\
\text { physicochemical and } \\
\text { antimicrobial properties } \\
\text { of gelatin film. }\end{array}$ & [1] \\
\hline $\begin{array}{l}\text { Food and } \\
\text { non-food } \\
\text { packaging }\end{array}$ & $\begin{array}{l}\text { Evaporative } \\
\text { casting/Film }\end{array}$ & $\begin{array}{c}\text { Fish gelatin } \\
(2.3 \% w / v), \text { chitosan } \\
(1 \% w / v), \text { glycerol } \\
(1 \% w / v)\end{array}$ & $\left(\mathrm{TiO}_{2}: \mathrm{Ag}\right): 0.4 \% w / w$ & $\begin{array}{l}\text { Hybrid films showed } \\
\text { improved } \\
\text { physicochemical and } \\
\text { antimicrobial properties. }\end{array}$ & [3] \\
\hline $\begin{array}{l}\text { Food and } \\
\text { non-food } \\
\text { packaging }\end{array}$ & $\begin{array}{l}\text { Evaporative } \\
\text { casting/Film }\end{array}$ & $\begin{array}{c}\text { Gelatin }(4 \mathrm{~g} \\
\left.100 \mathrm{~mL}^{-1}\right), \text { glycerol } \\
(25 \% w / w)\end{array}$ & $\begin{array}{l}\text { Commercial } \\
\left(\mathrm{TiO}_{2}\right): 1 \% w / w \\
\text { Size: }<10 \mathrm{~nm} \\
\text { CP: Anatase }\end{array}$ & $\begin{array}{c}\mathrm{TiO}_{2} \text { improved UV- } \\
\text { barrier, thermal, } \\
\text { mechanical, } \\
\text { and water-related } \\
\text { properties of gelatin film. }\end{array}$ & [12] \\
\hline $\begin{array}{l}\text { Food and } \\
\text { non-food } \\
\text { packaging }\end{array}$ & $\begin{array}{l}\text { Evaporative } \\
\text { casting/Film }\end{array}$ & $\begin{array}{c}\text { CMC }\left(1 \mathrm{~g} 100 \mathrm{~mL}^{-1}\right) \\
\text { gelatin }(1 \mathrm{~g} \\
\left.100 \mathrm{~mL}^{-1}\right)\end{array}$ & $\begin{array}{c}\text { Commercial } \\
\left(\mathrm{TiO}_{2}: \mathrm{Ag}\right): 0.4 \% w / w \\
\text { Size: } 20 \mathrm{~nm}\end{array}$ & $\begin{array}{c}\mathrm{TiO}_{2} \text { improved the } \\
\text { technological and } \\
\text { photocatalytic properties } \\
\text { of gelatin film. }\end{array}$ & [18] \\
\hline
\end{tabular}


Table 4. Cont.

\begin{tabular}{|c|c|c|c|c|c|}
\hline Application & Method/Presentation & *Composition & $\mathrm{TiO}_{2}$ Specifications & Relevant Results & Ref. \\
\hline $\begin{array}{l}\text { Food and } \\
\text { non-food } \\
\text { packaging }\end{array}$ & $\begin{array}{l}\text { Evaporative } \\
\text { casting/Film }\end{array}$ & $\begin{array}{c}\text { Gelatin }(4 \mathrm{~g} \\
\left.100 \mathrm{~mL}^{-1}\right), \text { glycerol } \\
(15 \% w / w)\end{array}$ & $\begin{array}{c}\text { SM: Sol-gel } \\
\left(\mathrm{TiO}_{2}: \mathrm{Ag}\right): 1 \% w / w \\
\text { Size: } 10-20 \mathrm{~nm} \\
\mathrm{CP}: \text { Anatase } \\
\text { Body-centered } \\
\text { tetragonal crystal } \\
\text { structure }\end{array}$ & $\begin{array}{l}\mathrm{TiO}_{2} \text { improved the } \\
\text { technological properties } \\
\text { of the gelatin film. }\end{array}$ & [20] \\
\hline $\begin{array}{l}\text { Food and } \\
\text { non-food } \\
\text { packaging }\end{array}$ & $\begin{array}{l}\text { Evaporative } \\
\text { casting/Film }\end{array}$ & 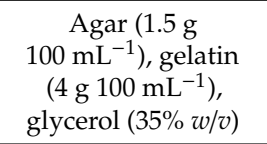 & $\begin{array}{c}\text { Commercial } \\
\left(\mathrm{TiO}_{2}\right): 0.5 \% w / w \\
\text { Size: } 10-20 \mathrm{~nm} \\
\text { CP: Anatase-Rutile }\end{array}$ & $\begin{array}{l}\text { The hybrid film showed } \\
\text { a marked UV-protective } \\
\text { effect and improved } \\
\text { water resistance. }\end{array}$ & [21] \\
\hline $\begin{array}{l}\text { Food and } \\
\text { non-food } \\
\text { packaging }\end{array}$ & $\begin{array}{l}\text { Evaporative } \\
\text { casting/Film }\end{array}$ & $\begin{array}{c}\text { Gelatin } \\
\left(15 \mathrm{mg} \cdot \mathrm{mL}^{-1}\right)\end{array}$ & $\begin{array}{l}\left(\mathrm{TiO}_{2}\right): 0.5 \% w / w \\
\text { Size: } 12.2 \mathrm{~nm} \\
\text { CP: Anatase } \\
\text { Crystal structure }\end{array}$ & $\begin{array}{l}\text { The film exhibits } \\
\text { antibacterial activity. }\end{array}$ & [26] \\
\hline $\begin{array}{l}\text { Food and } \\
\text { non-food } \\
\text { packaging }\end{array}$ & $\begin{array}{l}\text { Evaporative } \\
\text { casting/Film }\end{array}$ & $\begin{array}{l}\text { Gelatin }\left(3 \mathrm{~g} 80 \mathrm{~mL}^{-1}\right) \\
\text { PVA }\left(3 \mathrm{~g} 80 \mathrm{~mL}^{-1}\right) \\
\text { glycerol }(30 \% w / w)\end{array}$ & $\begin{array}{c}\text { Commercial } \\
\left(\mathrm{TiO}_{2}: 4 \mathrm{~A} \text { zeolite }\right): \\
1 \% w / w\end{array}$ & $\begin{array}{l}\text { Functionalization } \\
\text { improved the } \\
\text { physicochemical and } \\
\text { antimicrobial properties } \\
\text { of the gelatin-PVA film. }\end{array}$ & [74] \\
\hline $\begin{array}{l}\text { Food and } \\
\text { non-food } \\
\text { packaging }\end{array}$ & $\begin{array}{c}\text { Evaporative } \\
\text { casting/Coating }\end{array}$ & $\begin{array}{l}\text { Gelatin }\left(3 \mathrm{~g} 80 \mathrm{~mL}^{-1}\right), \\
\text { PVA }\left(3 \mathrm{~g} 80 \mathrm{~mL}^{-1}\right) \\
\text { glycerol }(30 \% w / w)\end{array}$ & $\begin{array}{c}\text { Commercial } \\
\left(\mathrm{TiO}_{2}: 4 \mathrm{~A} \text { zeolite }\right) \\
1 \% w / w\end{array}$ & $\begin{array}{l}\text { The hybrid film } \\
\text { effectively extended the } \\
\text { shelf life of white } \\
\text { shrimp. }\end{array}$ & [75] \\
\hline $\begin{array}{l}\text { Food and } \\
\text { non-food } \\
\text { packaging }\end{array}$ & $\begin{array}{l}\text { Evaporative } \\
\text { casting/Film }\end{array}$ & $\begin{array}{l}\text { Gelatin }(8 \% w / w) \text {, } \\
\text { sorbitol: glycerol } \\
\text { ratio 3:1 }(40 \% w / w)\end{array}$ & $\begin{array}{c}\text { Commercial } \\
\left(\mathrm{TiO}_{2}\right): 1 \% w / w \\
\text { Size: } 10-15 \mathrm{~nm} \\
\text { CP: Anatase-Rutile }\end{array}$ & $\begin{array}{l}\text { The hybrid film showed } \\
\text { antimicrobial properties. }\end{array}$ & [76] \\
\hline $\begin{array}{l}\text { Food and } \\
\text { non-food } \\
\text { packaging }\end{array}$ & $\begin{array}{l}\text { Evaporative } \\
\text { casting/Film }\end{array}$ & $\begin{array}{c}\text { Gelatin }(1 \mathrm{~g} \\
\left.100 \mathrm{~mL}^{-1}\right), \mathrm{CMC}(1 \mathrm{~g} \\
\left.100 \mathrm{~mL}^{-1}\right)\end{array}$ & $\begin{array}{c}\text { Commercial } \\
\left(\mathrm{TiO}_{2}: \mathrm{Ag}\right): 0.4 \% w / w \\
\text { Size: } 21 \mathrm{~nm} \\
\text { CP: Anatase }\end{array}$ & $\begin{array}{c}\text { Hybrid films showed } \\
\text { improved } \\
\text { physicochemical and } \\
\text { antimicrobial properties. }\end{array}$ & [77] \\
\hline $\begin{array}{l}\text { Food and } \\
\text { non-food } \\
\text { packaging }\end{array}$ & $\begin{array}{l}\text { Evaporative } \\
\text { casting/Film }\end{array}$ & $\begin{array}{c}\text { Gelatin }(4 \% w / w) \\
\text { agar }(1.5 \% w / v) \\
\text { glycerol }(35 \% w / w)\end{array}$ & $\begin{array}{c}\text { Commercial } \\
\left(\mathrm{TiO}_{2}\right): 2 \% w / w\end{array}$ & $\begin{array}{c}\text { Gelatin- } \mathrm{TiO}_{2} \text { effectively } \\
\text { delayed fish oil } \\
\text { oxidation. }\end{array}$ & [78] \\
\hline Biomedical & Freeze-drying/Hydrogel & $\begin{array}{c}\text { Sodium alginate }(2 \% \\
w / v), \text { gelatin }(0.5 \% \\
w / v), \beta-\operatorname{tP}(1 \% w / v)\end{array}$ & $\begin{array}{l}\text { SM: Electrochemical } \\
\text { anodization } \\
\left(\mathrm{TiO}_{2}\right): 0.1 \% w / v \\
\text { Size: } 110 \mathrm{~nm} \\
\mathrm{CP}: \text { Anatase } \\
\text { Nanotubes }\end{array}$ & $\begin{array}{l}\text { Hybrid hydrogel had } \\
\text { adequate porosity and } \\
\text { mechanical resistance. }\end{array}$ & [79] \\
\hline Biomedical & NI/Scaffold & NI & $\begin{array}{l}\text { SM: Biometic } \\
\left(\mathrm{TiO}_{2}\right): \mathrm{NI} \\
\text { Size: } 30-35 \mathrm{~nm} \\
\text { CP: Anatase }\end{array}$ & $\begin{array}{l}\text { Hybrid scaffold } \\
\text { promoted } \\
\text { osteointegration and } \\
\text { enhanced bone } \\
\text { regeneration. }\end{array}$ & [71] \\
\hline Biomedical & $\mathrm{NI} / \mathrm{NI}$ & Gelatin $\left(2 \mathrm{mg} \cdot \mathrm{mL}^{-1}\right)$ & $\begin{array}{c}\text { Electrochemical } \\
\text { anodization } \\
\left(\mathrm{TiO}_{2}\right): \mathrm{NI} \\
\text { Size: } 100 \mathrm{~nm} \\
\mathrm{CP}: \text { Rutile } \\
\text { Nanotubes } \\
(20 \mathrm{~nm} \times 350 \mathrm{~nm}) \\
\text { Low crystal structure }\end{array}$ & $\begin{array}{l}\text { Hybrid material could } \\
\text { potentially be used for } \\
\text { orthopedic and dental } \\
\text { applications. }\end{array}$ & [80] \\
\hline Biomedical & $\begin{array}{c}\text { Electrochemical } \\
\text { deposition/coating }\end{array}$ & $\begin{array}{l}\text { Hap (NI), Gelatin } \\
\left(100 \mathrm{mg} 100 \mathrm{~mL}^{-1}\right) \\
\text { GO }\left(2 \mathrm{mg} \mathrm{mL}^{-1}\right)\end{array}$ & $\begin{array}{l}\text { Hydrothermal } \\
\qquad\left(\mathrm{TiO}_{2}\right): \mathrm{NI} \\
\text { Crystal structure }\end{array}$ & $\begin{array}{l}\text { The hybrid coating } \\
\text { showed excellent } \\
\text { biocompatibility with } \\
\text { MC3T3-E1 cells. }\end{array}$ & [81] \\
\hline Biomedical & Freeze-drying/Hydrogel & $\begin{array}{l}\text { Gelatin }(2 \mathrm{~g} \\
\left.100 \mathrm{~mL}^{-1}\right)\end{array}$ & $\left(\mathrm{TiO}_{2}\right): 0.5 \% w / v$ & $\begin{array}{l}\text { The hybrid composite } \\
\text { had better } \\
\text { wound-healing } \\
\text { properties than } \\
\text { gelatin film. }\end{array}$ & [73] \\
\hline
\end{tabular}


Table 4. Cont.

\begin{tabular}{|c|c|c|c|c|c|}
\hline Application & Method/Presentation & *Composition & $\mathrm{TiO}_{2}$ Specifications & Relevant Results & Ref. \\
\hline Biomedical & $\begin{array}{l}\text { Polymer } \\
\text { blend/Biosensor }\end{array}$ & $\begin{array}{c}\text { CMC:Gelatin } \\
\text { (3.75 mg), solution of } \\
\text { superoxide } \\
\text { dismutase } \\
(4733 \mathrm{U}, 1 \mathrm{mg}), \\
\text { glutaraldehyde } \\
(0.005 \mathrm{M})\end{array}$ & $\begin{array}{l}\text { SM: Hydrothermal } \\
\left(\mathrm{TiO}_{2}\right): 0.1 \% w / w \\
\text { Size: } 50 \mathrm{~nm} \\
\text { CP: Anatase }\end{array}$ & $\begin{array}{l}\text { The biosensor exhibited } \\
\text { high analytical } \\
\text { performance, high } \\
\text { sensitivity, and fast } \\
\text { response time for } \\
\text { superoxide } \\
\text { radical detection. }\end{array}$ & [70] \\
\hline Pharmaceutical & NI/Capsule & Gelatin (NI) & $\begin{array}{c}\text { Commercial } \\
\left(\mathrm{TiO}_{2}\right): 3.5 \% w / w \\
\text { Size: } 177.2 \mathrm{~nm} \\
\mathrm{CP}: \text { Anatase } \\
\text { Crystalline structure }\end{array}$ & $\begin{array}{l}\text { The capsules could be } \\
\text { printed gray by UV-laser. }\end{array}$ & [82] \\
\hline $\begin{array}{l}\text { Metal } \\
\text { corrosion } \\
\text { resistance }\end{array}$ & NI/Coating & $\begin{array}{l}\text { Gelatin }(8 \text { wt. } \% \text { in } \\
20 \text { wt. } \% \text { acetic acid })\end{array}$ & $\begin{array}{c}\text { Commercial } \\
\left(\mathrm{TiO}_{2}\right): 3 \% w / w \\
\text { Size: } 10-25 \mathrm{~nm} \\
\text { CP: Anatase } \\
\text { Purity: }>99 \% \\
\text { Density: } 3.9 \mathrm{~g} \cdot \mathrm{cm}^{-3}\end{array}$ & $\begin{array}{c}\text { Gelatin- }-\mathrm{TiO}_{2} \text { composite } \\
\text { improved the corrosion } \\
\text { resistance of } \\
\text { steel material. }\end{array}$ & [83] \\
\hline $\begin{array}{l}\text { Hydrogen } \\
\text { production }\end{array}$ & $\mathrm{NI} /$ microspheres & $\begin{array}{l}\text { Gelatin }(5 \mathrm{~g} \\
\left.100 \mathrm{~mL}^{-1}\right)\end{array}$ & $\begin{array}{c}\text { SM: Sol-gel } \\
\text { Titania precursor }(10 \mathrm{~mL} \\
\text { of tetra-n-butyl titanate } \\
\text { in } 50 \mathrm{~mL} \text { of ethyl alcohol }) \\
\text { Size: } 50-100 \mathrm{~nm} \\
\text { CP: Anatase } \\
\text { High crystallinity and } \\
\text { purity }\end{array}$ & $\begin{array}{c}\text { Gelatin improved the } \\
\text { adsorptive properties } \\
\text { of } \mathrm{TiO}_{2} .\end{array}$ & [84] \\
\hline
\end{tabular}

* Material composition was based on the best-reported results. NI: No information; CMC: carboxymethyl cellulose; PVA: polyvinyl alcohol; GO: graphene oxide; $\beta$-tP: $\beta$-tricalcium phosphate; Hap: hydroxyapatite; SM: synthesis method; $\left(\mathrm{TiO}_{2}\right)$ : concentration of titanium dioxide; $\mathrm{CP}$ : crystallite phase.

\subsubsection{Food and Non-Food Packaging Applications of Gelatin- $\mathrm{TiO}_{2}$ Hybrid Composite}

The potential use of gelatin-based materials functionalized with $\mathrm{TiO}_{2}$ nanoparticles as food and non-food packaging material has been extensively explored [26,76]. Nassiri and Nafchi [76] developed a bovine gelatin film reinforced with $\mathrm{TiO}_{2}$ nanoparticles with antimicrobial properties against $S$. aureus and E. coli, associated with the physical and chemical interactions of $\mathrm{TiO}_{2}$ with the bacteria cell membrane. Incorporation of $\mathrm{TiO}_{2}$ at low concentrations $(5 \% w / w)$ decreases the water vapor (from 8.90 to $1.61 \times 10^{11} \mathrm{~g} \cdot \mathrm{m}^{-1} \cdot \mathrm{s}^{-1} \cdot \mathrm{Pa}^{-1}$ ), and oxygen permeability (from 214 to $95 \mathrm{~cm}^{3} \cdot \mu \mathrm{m} / \mathrm{m}^{2}$.day) of protein-based film. Similarly, Qingyan et al. [26] informed that gelatin- $\mathrm{TiO}_{2}$ film exhibited antimicrobial activity against E. coli (54\% inhibition of viable cells) and S. aureus ( $44 \%$ inhibition of viable cells) under UV-light irradiation ( $365 \mathrm{~nm}$ ) after $120 \mathrm{~min}$ of exposure. The above, associated with the photocatalytic properties of $\mathrm{TiO}_{2}$ and its ability to generate reactive molecules (hydrogen peroxide, hydroxyl radical, and superoxide anions) with antimicrobial properties by affecting the cell viability. Moreover, the addition of $\mathrm{TiO}_{2}(1 \% w / w$ of total solid content) in the gelatin film promoted an increase in its mechanical and thermal properties. It decreased water solubility, moisture uptake, water vapor permeability, and transparency due to the formation of hydrogen and $\mathrm{Ti}-\mathrm{O}-\mathrm{C}$ bonds and electrostatic interactions between protein and inorganic nanoparticles [12].

Azizi-Lalabadi et al. [74] made a hybrid film composed of gelatin and polyvinyl alcohol, reinforced with $\mathrm{TiO}_{2}$ nanoparticles previously embedded in $4 \mathrm{~A}$-zeolite. The enhanced physicochemical (optical, gas-barrier, and water resistance) were attributed to the interaction of the $\mathrm{N}-\mathrm{H}$ functional group present in the protein structure, with $\mathrm{TiO}_{2}$ through hydrogen bonds. Moreover, the hybrid film exhibited antimicrobial properties especially against Gram-negative bacteria (E. coli and P. fluorescens). Moreover, the hybrid film effectively extended the shelf life of white shrimp (up to 12 days) compared to uncoated samples (6 days), without significant changes in sensory attributes [75]. Likewise, Riahi et al. [1] fabricated an active gelatin- $\mathrm{TiO}_{2}$-grape seed extract film for food packaging purposes and found that water contact angle, water vapor permeability, mechanical properties, and UV-protective effect 
improved in a dose-dependent response with an optimum $\mathrm{TiO}_{2}$ concentration of $0.5 \% w / w$, which was attributed to the chemical interaction of $\mathrm{TiO}_{2}$ and $\mathrm{C}=\mathrm{O}$ groups in the protein structure. On the other hand, the hybrid film exhibited antimicrobial activity in strain- and $\mathrm{TiO}_{2}$ dose-dependence, where the Gram-negative bacteria were less susceptible than Gram-positive. At low concentrations of $\mathrm{TiO}_{2}$ $(<3 \% w / w)$, the hybrid film showed a bacteriostatic effect against $E$. coli and L. monocytogenes, while at $5 \% w / w$ exhibited bactericidal action.

Pirsa et al. [77] evaluated the antioxidant and antimicrobial properties of a carboxymethyl cellulose-gelatin film reinforced with $\mathrm{TiO}_{2}$ :Ag-doped nanoparticles. The hybrid film exhibited better mechanical properties (greater flexibility) in comparison with the control group. Moreover, it showed antioxidant activity and antibacterial effect against E. coli and S. aureus in a $\mathrm{TiO}_{2}: \mathrm{Ag}$ concentration-dependent response. Furthermore, the carboxymethyl cellulose (CMC)-gelatin- $\mathrm{TiO}_{2}$ : Ag exhibited good photocatalytic degradation of ethanol, benzene, and ammonia [18]. Furthermore, the incorporation of $\mathrm{TiO}_{2}$ : Ag-doped nanoparticles improved the antioxidant, mechanical, UV-barrier, water resistance, and mechanical properties of a Rhinobatos cemiculus gelatin film in a dose-dependent manner. At a low concentration of $\mathrm{TiO}_{2}$, it can disperse uniformly and insert in the amorphous region of soy protein isolate (SPI), leading to a major interaction between both components; however, at high concentrations of $\mathrm{TiO}_{2}$, it could cause agglomerations interfering with the organization and interaction of protein and $\mathrm{TiO}_{2}[16]$.

Similar results were reported in a fish gelatin-chitosan film functionalized with $\mathrm{TiO}_{2}: \mathrm{Ag}$ nanoparticles, where the improved antibacterial activity (E. coli, S. aureus, and Botrytis cinerea), optical, water-related, and mechanical properties were in a $\mathrm{TiO}_{2}: \mathrm{Ag}$ dose-dependent response [3]. The addition of $\mathrm{TiO}_{2}$ :Ag-doped nanoparticles did not alter the typical structure of biopolymers, but instead promoted stronger intramolecular hydrogen bonds formation $[16,85]$. On the other hand, it has been reported that the improved UV-protective effects, water-related, and mechanical properties of a fish gelatin-agar- $\mathrm{TiO}_{2}$ film could be negatively affected by a high concentration of $\mathrm{TiO}_{2}\left(>0.5 \mathrm{~g} 100 \mathrm{~mL}^{-1}\right)$, mainly by an inhomogeneous dispersion and saturation of nanoparticles in the protein structure [21].

Additionally, Vejdan et al. [78] informed that a gelatin-agar bilayer film functionalized with $\mathrm{TiO}_{2}$ nanoparticles effectively delays fish oil photo- and auto-oxidation up to 18 days. They reported that hybrid film containing $2 \%$ of $\mathrm{TiO}_{2}$ could control fish oil oxidation due to the enhanced UV-protective and oxygen-barrier properties associated with the physicochemical characteristics of $\mathrm{TiO}_{2}$.

According to the results, incorporation of $\mathrm{TiO}_{2}$ into the gelatin-matrix improved its mechanical, thermal, UV-protective, gas-barrier, and water-related properties with antioxidant and antimicrobial performance, both desirable characteristics for the development of food and non-food packaging materials.

\subsubsection{Biomedical Applications of Gelatin- $-\mathrm{TiO}_{2}$ Hybrid Composite}

Gelatin- $\mathrm{TiO}_{2}$ hybrid composites have been used for biomedical purposes. Lai et al. [80] immobilized gelatin onto $\mathrm{TiO}_{2}$ nanotubes to modulate osteoblast behavior for orthopedic and dental applications. The authors found that cell spreading, proliferation, and differentiation of osteoblasts were improved by gelatin- $\mathrm{TiO}_{2}$ hybrid material. They argued that extracellular matrix protein-based plays an important role in bone mineralization, while $\mathrm{TiO}_{2}$ present in the hybrid matrix facilitates osteoblast differentiation. Ferreira et al. [71] fabricated a macroporous $\mathrm{TiO}_{2}$-functional hydroxyapatite-gelatin scaffold loaded with multipotent adult progenitor cells for bone regeneration applications in calvaria defects. They informed that a hybrid scaffold promoted osteointegration and enhanced bone regeneration with complete closure defect. The result was associated with the ability of $\mathrm{TiO}_{2}$ to form complexes with calcium ions, promoting the adsorption of calcium-binding extracellular matrix proteins and Argine-Glycine-Aspartate specific peptide sequences.

Additionally, hydroxyapatite-gelatin-graphene oxide composite deposited on $\mathrm{TiO}_{2}$ nanotubes by electrochemical deposition exhibited excellent biocompatibility with MC3T3-E1 cells, promoting a better cellular integration [81]. Moreover, Urruela-Barrios et al. [79] mentioned that a sodium 
alginate-gelatin hydrogel 3D printing functionalized with nano- $\mathrm{TiO}_{2}$ and $\beta$-tricalcium phosphate exhibited a potential use for tissue engineering application. The hybrid material fabricated with the micro-extrusion process, exhibited adequate porosity (pore size ranged from 150 to $240 \mu \mathrm{m}$ ), and mechanical resistance (13 MPa) to promote cell proliferation and cartilages.

Nikpasand and Reza-Parvizi [73] evaluated in vivo the wound dressing properties of a gelatin- $\mathrm{TiO}_{2}$ hybrid hydrogel in an open and infected with $S$. aureus methicillin-resistant at $5 \times 10^{7}$ colony forming units (CFU) by excision-type wound-healing study in rats. They found that the hybrid composite exhibited a good wound-healing effect (wound area closure of $100 \%$ after 21 days), in comparison with gelatin-wound treatments (wound area closure of $71 \%$ after 21 days). Nonetheless, animals treated with the hybrid composite did not show wound infection by pathogenic bacteria after 14 days of evaluation and exhibited accelerated re-epithelization through fibroblast proliferation without inflammatory response after 21 days, which could be considered for wound therapies. On the other hand, Emregul et al. [70] developed a carboxymethyl cellulose-gelatin- $\mathrm{TiO}_{2}$-superoxide dismutase biosensor supported in $\mathrm{Pt}$ surface for $\mathrm{O}_{2}{ }^{\bullet-}$ detection. They reported that the biopolymer blend (CMC and gelatin), provided a biocompatible environment for super oxide dismutase- $\mathrm{TiO}_{2}$, which acts as a nanoscale electrode, enhancing the electron transfer rate through the Pt electrode. The hybrid sensor exhibited high analytical performance with a wide linear range of $1.5 \mathrm{nM}$ to $2 \mathrm{mM}$, and high sensitivity and fast response time (1.8 s) for $\mathrm{O}_{2}{ }^{--}$detection in healthy and cancerous brain tissue (coefficient of determination or $R^{2}$ of 0.991 ). In this context, functionalization of gelatin-based materials with $\mathrm{TiO}_{2}$ exhibited potential biomedical applications, associated with its enhanced biological properties.

\subsubsection{Other Applications of Gelatin- $\mathrm{TiO}_{2}$ Hybrid Composite}

Other investigated applications of the gelatin- $\mathrm{TiO}_{2}$ hybrid composite include pharmaceutical (development of empty capsule shells), anti-corrosive material, and hydrogen storage. Hosokawa et al. [82] evaluated the application of UV-laser irradiation (at $355 \mathrm{~nm}$ ) to print hard gelatin capsule shells with $\mathrm{TiO}_{2}$, and it was found that hybrid capsules could be printed gray in a laser power-dependent response.

Additionally, Hayajneh et al. [83] studied the effect of gelatin- $\mathrm{TiO}_{2}$ hybrid coating on the corrosion resistance of AISI 304 stainless steel, in a simulated marine environment (solution with $\mathrm{NaCl}$ at 3.5\% $w / v)$ through potentiodynamic polarization studies. The presence of hybrid coating improved the corrosion resistance of steel material (corrosion rate $2.63 \times 10^{-3} \mathrm{mpy}$ ) in comparison with gelatin-coated (corrosion rate $10.10 \times 10^{-3} \mathrm{mpy}$ ) and uncoated (corrosion rate $9.94 \times 10^{-3} \mathrm{mpy}$ ) steel. The results were associated with the formation of a dense and stable network structure formed by the gelatin and $\mathrm{TiO}_{2}$ nanoparticles.

Furthermore, Bin Liu et al. [84] used gelatin as a template to fabricate $\mathrm{TiO}_{2}$ mesoporous microspheres for hydrogen production. They reported that the assistance of gelatin positively influenced the morphology and physicochemical characteristics of $\mathrm{TiO}_{2}$ nanoparticles (surface area of $98.3 \mathrm{~m}^{2} \cdot \mathrm{g}^{-1}$ and pore size of $11.9 \mathrm{~nm}$ ), enhancing the hydrogen adsorption capacity and hydrogen storage performance of hybrid microspheres. However, its hydrogen adsorption mechanism remains unclear. According to these data, the gelatin- $\mathrm{TiO}_{2}$ hybrid material exhibited pharmaceutical, anti-corrosive, and hydrogen production applications.

\subsection{Whey Protein- $\mathrm{TiO}_{2}$ Hybrid Composite}

Whey protein is a by-product obtained from dairy processing during cheese production. It is used to develop edible films and coatings with good biodegradability and lower gas permeability for diverse applications [29]. However, the potential uses of whey protein-based materials are limited by their higher hydrophilicity due to polar residues outside the globular structure, which causes softening when they come in contact with high-moisture environments [86]. On the other hand, it exhibited good biocompatibility to interact with inorganic compounds like $\mathrm{TiO}_{2}$ to improve its technological and functional properties [29]. The most common method for preparing whey protein- $\mathrm{TiO}_{2}$ hybrid composites is evaporative casting. Furthermore, the nanoparticles used are commercially available 
with sizes ranging from 10 to $25 \mathrm{~nm}$ in its anatase phase and using concentrations $\leq 1 \%$ in weight of total solid content, as listed in Table 5.

Table 5. Effect of $\mathrm{TiO}_{2}$ incorporation on whey protein matrix properties.

\begin{tabular}{|c|c|c|c|c|c|}
\hline Application & Method/Presentation & * Composition & $\mathrm{TiO}_{2}$ Specifications & Relevant Results & Ref. \\
\hline $\begin{array}{l}\text { Food and } \\
\text { non-food } \\
\text { packaging }\end{array}$ & $\begin{array}{l}\text { Evaporative } \\
\text { casting/Film }\end{array}$ & WPI $(10 \% w / w)$ & $\begin{array}{c}\text { Commercial } \\
\left(\mathrm{TiO}_{2}\right): 0.25 \% w / w \\
\text { Size: } 50-100 \mathrm{~nm} \\
\text { CP: Anatase } \\
\text { Purity: }>98.5 \%\end{array}$ & $\begin{array}{l}\mathrm{TiO}_{2} \text { improved the } \\
\text { physicochemical } \\
\text { properties of whey } \\
\text { protein film. }\end{array}$ & [17] \\
\hline $\begin{array}{l}\text { Food and } \\
\text { non-food } \\
\text { packaging }\end{array}$ & $\begin{array}{l}\text { Evaporative } \\
\text { casting/Film }\end{array}$ & $\begin{array}{l}\text { WPI }(10 \% w / v) \\
\text { cellulose }(1 \% w / v) \text {, } \\
\text { glycerol }(6 \% w / v) \\
\text { REO }(2 \% w / v)\end{array}$ & $\begin{array}{l}\text { Commercial } \\
\left(\mathrm{TiO}_{2}\right): 1 \% w / v \\
\text { Size: } 10-25 \mathrm{~nm} \\
\text { CP: Anatase }\end{array}$ & $\begin{array}{l}\text { Coated meat exhibited } \\
\text { microbial stability } \\
\text { during cold storage. }\end{array}$ & [28] \\
\hline $\begin{array}{l}\text { Food and } \\
\text { non-food } \\
\text { packaging }\end{array}$ & $\begin{array}{l}\text { Evaporative } \\
\text { casting/Film }\end{array}$ & $\begin{array}{c}\text { WPI nanofibers }(5 \% \\
w / v), \text { glycerol }(4 \% \\
w / v)\end{array}$ & $\begin{array}{l}\text { Commercial } \\
\left(\mathrm{TiO}_{2}\right): 1 \% w / w \\
\text { Size: } 20 \mathrm{~nm} \\
\text { Nanotubes } \\
\text { Purity: }>99 \%\end{array}$ & $\begin{array}{l}\text { The hybrid film } \\
\text { effectively extends the } \\
\text { shelf life of chilled meat. }\end{array}$ & [29] \\
\hline $\begin{array}{l}\text { Food and } \\
\text { non-food } \\
\text { packaging }\end{array}$ & $\begin{array}{l}\text { Evaporative } \\
\text { casting/Film }\end{array}$ & $\begin{array}{c}\text { WPI }(5 \% w / v) \\
\text { kefiran }(5 \% w / v) \\
\text { glycerol }(35 \% w / w)\end{array}$ & 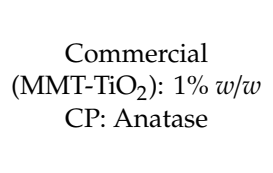 & $\begin{array}{l}\mathrm{TiO}_{2} \text { improved the } \\
\text { physicochemical } \\
\text { properties of } \\
\text { kefiran-whey protein } \\
\text { film. }\end{array}$ & [31] \\
\hline $\begin{array}{l}\text { Food and } \\
\text { non-food } \\
\text { packaging }\end{array}$ & $\begin{array}{l}\text { Evaporative } \\
\text { casting/Film }\end{array}$ & $\begin{array}{l}\text { WPI }(10 \% w / v) \\
\text { cellulose }(1 \% w / v) \text {, } \\
\text { glycerol }(6 \% w / v) \\
\operatorname{REO}(2 \% w / v)\end{array}$ & $\begin{array}{l}\text { Commercial } \\
\left(\mathrm{TiO}_{2}\right): 1 \% w / v \\
\text { Size: } 10-25 \mathrm{~nm} \\
\text { CP: Anatase } \\
\text { Purity: }>99 \%\end{array}$ & $\begin{array}{l}\text { The hybrid film } \\
\text { exhibited antimicrobial } \\
\text { and antioxidant } \\
\text { properties. }\end{array}$ & [86] \\
\hline $\begin{array}{l}\text { Food and } \\
\text { non-food } \\
\text { packaging }\end{array}$ & $\begin{array}{l}\text { Evaporative } \\
\text { casting/Film }\end{array}$ & $\begin{array}{c}\text { WPI }(5 \% w / v), \mathrm{TiO}_{2} \\
(1 \% w / w), \text { glycerol } \\
(5 \% w / v)\end{array}$ & $\begin{array}{l}\text { Commercial } \\
\left(\mathrm{TiO}_{2}\right): 1 \% w / w \\
\text { Size: }<20 \mathrm{~nm} \\
\text { CP: Anatase }\end{array}$ & $\begin{array}{l}\mathrm{TiO}_{2} \text { improved the } \\
\text { physicochemical } \\
\text { properties of whey } \\
\text { protein film. }\end{array}$ & [87] \\
\hline $\begin{array}{l}\text { Food and } \\
\text { non-food } \\
\text { packaging }\end{array}$ & $\begin{array}{l}\text { Evaporative } \\
\text { casting/Film }\end{array}$ & $\begin{array}{l}\text { WPI }(10 \% w / v) \text {, } \\
\text { cellulose }(1 \% w / v) \text {, } \\
\text { glycerol }(6 \% w / v) \\
\operatorname{REO}(2 \% w / v)\end{array}$ & $\begin{array}{l}\text { Commercial } \\
\left(\mathrm{TiO}_{2}\right): 1 \% w / v \\
\text { Size: } 10-25 \mathrm{~nm} \\
\text { CP: Anatase } \\
\text { Purity: }>99 \%\end{array}$ & $\begin{array}{l}\text { Meat treated with the } \\
\text { hybrid film showed } \\
\text { reduced lipid } \\
\text { peroxidation during cold } \\
\text { storage. }\end{array}$ & [88] \\
\hline $\begin{array}{l}\text { Food and } \\
\text { non-food } \\
\text { packaging }\end{array}$ & $\begin{array}{l}\text { Evaporative } \\
\text { casting/Film }\end{array}$ & $\begin{array}{l}\text { Chitosan }(1.5 \mathrm{~g} \\
50 \mathrm{~mL}^{-1} \text { of acetic } \\
\text { acid), WPI ( } 0.5 \mathrm{~g} \\
\left.50 \mathrm{~mL}^{-1} \text { of water }\right)\end{array}$ & $\begin{array}{c}\text { Commercial } \\
\left(\mathrm{TiO}_{2}\right): 0.01 \mathrm{~g} \\
\mathrm{CP}: \text { Anatase } \\
\text { Crystalline structure }\end{array}$ & $\begin{array}{c}\text { The hybrid film } \\
\text { exhibited improved } \\
\text { physicochemical } \\
\text { properties. }\end{array}$ & [89] \\
\hline $\begin{array}{l}\text { Food and } \\
\text { non-food } \\
\text { packaging }\end{array}$ & $\begin{array}{l}\text { Evaporative } \\
\text { casting/Film }\end{array}$ & $\begin{array}{c}\text { WPI }(5 \% w / v) \\
\text { kefiran }(5 \% w / v) \\
\text { glycerol }(35 \% w / w)\end{array}$ & 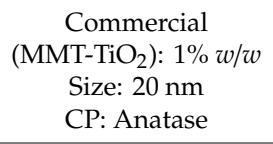 & $\begin{array}{c}\text { The hybrid film } \\
\text { exhibited improved } \\
\text { physicochemical } \\
\text { properties. }\end{array}$ & [90] \\
\hline $\begin{array}{l}\text { Food and } \\
\text { non-food } \\
\text { packaging }\end{array}$ & $\begin{array}{l}\text { Evaporative } \\
\text { casting/Film }\end{array}$ & $\begin{array}{c}\text { WPI }(3 \% w / v) \\
\text { chitosan }(10 \mathrm{~g} / \mathrm{L}) \\
\text { ZMEO }(1 \% v / v) \\
\text { glycerol }(30 \% w / w)\end{array}$ & $\begin{array}{c}\text { Commercial } \\
\left(\mathrm{TiO}_{2}\right): 2 \% w / w \\
\text { CP: Anatase-Rutile }\end{array}$ & $\begin{array}{l}\text { The hybrid film } \\
\text { exhibited antimicrobial } \\
\text { activity. }\end{array}$ & [91] \\
\hline Textile & $\begin{array}{l}\text { Dip-pad-dry-cure } \\
\text { process/Coating }\end{array}$ & $\begin{array}{l}\text { WPI }(3 \% w / v), \text { cotton } \\
\text { fabrics }\left(200 \mathrm{~g} / \mathrm{m}^{2}\right)\end{array}$ & $\begin{array}{l}\text { Commercial } \\
\left(\mathrm{TiO}_{2}\right): 6 \% w / w\end{array}$ & $\begin{array}{l}\text { The hybrid coating } \\
\text { exhibited improved } \\
\text { antimicrobial activity. }\end{array}$ & [92] \\
\hline
\end{tabular}

* Material composition was based on the best-reported results. NI: No information; WPI: whey protein isolate; REO: rosemary essential oil; MMT: montmorillonite; ZMEO: Zataria multiflora essential oil.; SM: synthesis method; $\left(\mathrm{TiO}_{2}\right)$ : concentration of titanium dioxide; $\mathrm{CP}$ : crystallite phase.

\subsubsection{Food and Non-Food Packaging Applications of Whey Protein- $-\mathrm{TiO}_{2}$ Hybrid Composite}

The potential use of whey protein- $\mathrm{TiO}_{2}$ hybrid material for food packaging purposes has been investigated [28], as shown in Table 5. Zhou et al. [87] prepared a biodegradable whey protein film functionalized with $\mathrm{TiO}_{2}$. It was found that technological properties such as UV-protective, mechanical, and water-resistance properties were improved in a $\mathrm{TiO}_{2}$ dose-dependent response, 
associated with the intramolecular connections of protein and $\mathrm{TiO}_{2}$ through covalent and non-covalent interactions. Moreover, the authors argued that at low concentrations of $\mathrm{TiO}_{2}$, a reinforcement of whey protein- $\mathrm{TiO}_{2}$ structure occurs. Meanwhile, self-assembly of $\mathrm{TiO}_{2}-\mathrm{TiO}_{2}$ interactions are detected at high $\mathrm{TiO}_{2}$ concentrations, influencing its technological and functional properties, mainly associated with a reduction in the crystalline structure of $\mathrm{TiO}_{2}$ by its incorporation in a polymeric matrix and its tendency to form agglomerates at higher concentrations [17,31]. Similar trends were informed in a kefiran-whey protein film functionalized with $\mathrm{TiO}_{2}$, where an excessive amount of $\mathrm{TiO}_{2}$ in the polymeric matrix affected its functionality because $\mathrm{TiO}_{2}$ may act as an anti-plasticizer agent $[31,90]$. Moreover, in a combined chitosan-whey protein film reinforced with sodium laurate- $\mathrm{TiO}_{2}$ nanoparticles. Zhang et al. [89] reported that sodium laurate-modified $\mathrm{TiO}_{2}$ incorporation influenced the transparency, water vapor permeability, and mechanical and thermal properties of the hybrid film in a dose-dependent manner, and its intermolecular interaction with the available functional groups of the chitosan-whey protein matrix. Gohargani et al. [91] fabricated a chitosan-whey protein film, functionalized with $\mathrm{TiO}_{2}$ and Zataria multiflora essential oil (ZMEO) nanoparticles with enhanced antimicrobial properties against foodborne pathogenic bacteria such as L. monocytogenes, S. aureus, and E. coli. Results were attributed to the synergistic effect of bioactive compounds present in the $\mathrm{ZMEO}$ and $\mathrm{TiO}_{2}$ nanoparticles. Moreover, the $\mathrm{TiO}_{2}-\mathrm{ZMEO}$ incorporation into the hybrid film, improved water vapor permeability, and tensile strength with a significant decrease in the film's transparency and color, associated with the physicochemical properties of $\mathrm{TiO}_{2}$.

Alizadeh-Sani et al. [28] informed that a whey protein isolate-cellulose nanofiber- $\mathrm{TiO}_{2}$-rosemary essential oil (REO) effectively preserved quality (microbial deterioration and sensory attributes) of refrigerated meat during cold storage. They reported that lamb meat treated with the hybrid film showed microbial stability ( $4.1 \mathrm{log} \cdot \mathrm{CFU} \cdot \mathrm{g}^{-1}$ of viable cells) for 6 days at $4{ }^{\circ} \mathrm{C}$ storage without changes in sensory attributes (color, odor, texture, and overall acceptability). Moreover, the treated meat exhibited reduced lipid oxidation during storage, ascribed to antioxidant properties of REO ( $80 \%$ of radical scavenging) [88]. Furthermore, the $\mathrm{TiO}_{2}(1 \% w / w)$ and $\mathrm{REO}(2 \% w / w)$ addition in the whey protein isolate/cellulose nanofiber hybrid film, improved mechanical (tensile strength, elongation at break, and elastic modulus) and water-related properties (moisture uptake, water solubility, and water vapor permeability), with a decrease in its transparency in a dose-dependent response in comparison with whey protein-based film, associated with the UV-scattering ability of $\mathrm{TiO}_{2}$. Furthermore, the hybrid film showed an antimicrobial effect against foodborne bacteria (E. coli O157:H7, L. monocytogenes, P. fluorescens, and S. enteritidis) in a strain-dependent manner. It was associated with antimicrobial properties of $\mathrm{TiO}_{2}$ and bioactive compounds (1,8-cineole, $\alpha$-pinene, and camphor) in the REO; which can alter the cell membrane and finally cause cell death [86]. Nonetheless, they informed that a low content of $\mathrm{TiO}_{2}$ migrated from the polymeric matrix to the meat product, under the Food and Drug Administration limit recommendations $(<1 \% w / w)$ [88]. Similarly, Feng et al. [29] informed that a whey protein- $\mathrm{TiO}_{2}$ hybrid film is effective in extending the shelf life of chilled meat (up to 15 days) without significant changes in its quality parameters (weight loss less than $7.87 \%$, reduced lipid peroxidation, and microbial stability) during cold storage $\left(4{ }^{\circ} \mathrm{C}\right)$. Moreover, the hybrid film exhibited enhanced mechanical, optical, and water-related properties associated with the physical and chemical interactions between carboxylic and sulfhydryl groups of some amino acids present in the protein matrix with $\mathrm{TiO}_{2}$.

According to the evidence, the incorporation of $\mathrm{TiO}_{2}$ into whey protein-based materials can improve the thermal, UV-barrier, mechanical, and water-related properties through physical and chemical interactions. Furthermore, whey protein films functionalized with $\mathrm{TiO}_{2}$ exhibited antimicrobial properties for potential food and non-food packaging.

\subsubsection{Other Applications of Whey Protein- $-\mathrm{TiO}_{2}$ Hybrid Composite}

Ortelli et al. [92] fabricated a hybrid cotton fabric with anti-fire properties incorporating a whey protein- $\mathrm{TiO}_{2}$ coating by the dip-pad-dry-cure process (Table 5). In general, the hybrid cotton material showed major durability (resistance to washing) and flame-resistant compared with the control group 
because $\mathrm{TiO}_{2}$ acts as a physical reinforcement agent to fix whey protein to cotton fabrics in a stable way with the hydroxyl groups.

\subsection{Collagen-TiO $\mathrm{O}_{2}$ Hybrid Composite}

Collagen is a large, coherent, covalently crosslinked fibrillar network protein. Its main sources are porcine, bovine, and ovine with many applications in the food, cosmetics, pharmaceutical, and biomedical industries [34]. The disadvantages of collagen are poor thermal instability, poor mechanical properties, and the possible contamination by pathogenic bacteria and chemical substances [93]. Particularly, collagen has been combined with $\mathrm{TiO}_{2}$ to improve its physicochemical properties [5]. Preparation of collagen- $\mathrm{TiO}_{2}$ hybrid composites is usually by dip-coating, followed by freeze-drying for aerogel development. Furthermore, the nanoparticles used are commercially available or synthesized by the Sol-gel method with sizes ranging from 10 to $30 \mathrm{~nm}$ in its anatase phase, and in some cases in its rutile phase (Table 6).

Table 6. Effect of $\mathrm{TiO}_{2}$ incorporation on collagen-based materials.

\begin{tabular}{|c|c|c|c|c|c|}
\hline Application & Method/Presentation & *Composition & $\mathrm{TiO}_{2}$ Specifications & Relevant Results & Ref. \\
\hline Biomedical & Dip coating/Composite & $\begin{array}{l}\text { Collagen-MWCNTs } \\
\text { composite coated Ti } \\
\text { incorporated with } \\
20 \mu \mathrm{g} / \mathrm{cm}^{2} \text { of MWCNTs }\end{array}$ & $\begin{array}{l}\text { Commercial } \\
\left(\mathrm{TiO}_{2}\right): \mathrm{NI}\end{array}$ & $\begin{array}{l}\text { The high roughness of } \\
\text { hybrid materials } \\
\text { improved cell } \\
\text { proliferation. }\end{array}$ & [5] \\
\hline Biomedical & Dip coating/NI & $\begin{array}{c}\text { Volume ratio } 1: 1.5 \\
\text { GPTMS-TiO } \\
\text { into a Collagen } \\
\text { solution }\left(3 \mathrm{mg} \cdot \mathrm{mL}^{-1}\right) \\
\text { to cover the } \mathrm{Mg} \text { alloys }\end{array}$ & $\begin{array}{c}\text { SM: Sol-gel } \\
\left(\mathrm{TiO}_{2}\right): \text { NI } \\
\mathrm{TiO}_{2} \text { with an } \\
\text { amorphous structure }\end{array}$ & $\begin{array}{l}\text { Protect alloy from } \\
\text { corrosion, promote } \\
\text { fibroblast proliferation. }\end{array}$ & [93] \\
\hline Biomedical & NI/Film & Collagen $\left(0.5 \mathrm{mg} \cdot \mathrm{m}^{-1}\right)$ & $\begin{array}{c}\text { SM: Electrochemical } \\
\text { deposition } \\
\left(\mathrm{TiO}_{2}\right): \mathrm{NI} \\
\mathrm{TiO}_{2} \text { with a crystalline } \\
\text { structure }\end{array}$ & $\begin{array}{l}\text { The hybrid film showed } \\
\text { rapid cell adhesion and } \\
\text { proliferation. }\end{array}$ & [94] \\
\hline Biomedical & $\begin{array}{c}\text { Atomic layer } \\
\text { deposition/Membrane }\end{array}$ & $\begin{array}{l}\text { Collagen membrane } \\
(25 \mathrm{~mm} \times 15 \mathrm{~mm})\end{array}$ & $\begin{array}{l}\text { Commercial } \\
\left(\mathrm{TiO}_{2}\right): \mathrm{NI}\end{array}$ & $\begin{array}{l}\text { The hybrid membrane } \\
\text { exhibited the } \\
\text { proliferation of } \\
\text { osteoblast. }\end{array}$ & [96] \\
\hline Biomedical & NI/Composite & $\begin{array}{c}\text { Mol ratio } 1: 1 \text { of } \\
\text { PdO-TiO } \\
\text { incorporated to } \\
\text { g-PMMA-Collagen }\end{array}$ & $\begin{array}{l}\text { SM: Sol-gel } \\
\left(\mathrm{TiO}_{2}\right): \mathrm{NI} \\
\text { Size: } 8 \mathrm{~nm} \\
\mathrm{CP}: \text { Anatase }\end{array}$ & $\begin{array}{l}\mathrm{TiO}_{2} \text { incorporation } \\
\text { improved thermal } \\
\text { stability, mechanical } \\
\text { strength, } \\
\text { and enhancement of } \\
\text { collagen. }\end{array}$ & [97] \\
\hline $\begin{array}{l}\text { Non-food } \\
\text { packing }\end{array}$ & $\mathrm{NI} / \mathrm{NI}$ & $\begin{array}{l}\text { Collagen }(4 \mathrm{~g} \\
\left.100 \mathrm{~mL}^{-1}\right)\end{array}$ & $\begin{array}{l}\text { SM: Sol-gel } \\
\left(\mathrm{TiO}_{2}\right): 2 \% w / w \\
\text { Size: } 30 \mathrm{~nm} \\
\text { CP: Anatase }\end{array}$ & $\begin{array}{l}\mathrm{TiO}_{2} \text { increases the } \\
\text { thermal stability of } \\
\text { collagen film improves } \\
\text { and reduces UV light } \\
\text { penetration, } \\
\text { and solubility. }\end{array}$ & [98] \\
\hline
\end{tabular}


Table 6. Cont.

\begin{tabular}{|c|c|c|c|c|c|}
\hline Application & Method/Presentation & * Composition & $\mathrm{TiO}_{2}$ Specifications & Relevant Results & Ref. \\
\hline $\begin{array}{l}\text { Environmental } \\
\text { remediation }\end{array}$ & Dip coating/NI & Collagen (template) & $\begin{array}{c}\left(\mathrm{TiO}_{2}: \mathrm{Tb}^{3+}\right): 2 \% w / w \\
\text { Size: } 9.6 \mathrm{~nm} \\
\text { CP: Anatase }\end{array}$ & $\begin{array}{l}\text { Collagen structure was } \\
\text { preserved and } \\
\text { photocatalytic } \\
\text { performance of } \mathrm{TiO}_{2} \\
\text { increased. }\end{array}$ & [99] \\
\hline $\begin{array}{c}\text { Electrochemical } \\
\text { studies }\end{array}$ & Chemical reactions/NI & NI & $\begin{array}{l}\text { SM: Template } \\
\left(\mathrm{TiO}_{2}\right): \mathrm{NI} \\
\text { Size: } 10-20 \mathrm{~nm} \\
\text { CP: Anatase }\end{array}$ & $\begin{array}{l}\text { Hybrid material showed } \\
\text { excellent electrochemical } \\
\text { lithium and sodium } \\
\text { storage properties. }\end{array}$ & [100] \\
\hline
\end{tabular}

\subsubsection{Biomedical Applications of Collagen- $\mathrm{TiO}_{2}$ Hybrid Composite}

Table 6 lists, works on collagen-based materials functionalized with $\mathrm{TiO}_{2}$ for biomedical applications. Park et al. [5] evaluated the effect of collagen-multi-walled carbon nanotubes (MWCNTs) composite coating deposited on titanium, using a dip-coating method on osteoblast growth. Cell proliferation studies confirmed a strong dependence of the extent of cell proliferation on the amount of MWCNTs incorporated in the composite in a dose-dependent response. Collagen-MWCNT-Ti showed higher cell proliferation than the collagen-MWCNT composite, where $\mathrm{TiO}_{2}$ was responsible for cell proliferation. Truc et al. [94] studied the interaction between fibroblast and collagen modified on titanium (Ti) surface by electrochemical deposition (ECD), to reduce dental implant failure. They found that the Ti/Collagen hybrid composite showed rapid cell adhesion and proliferation.

Nojiri et al. [95] evaluated the establishment of perpendicularly oriented collagen attachments on $\mathrm{TiO}_{2}$ nanotubes (TNT), which exhibited significant binding resistance, and the chemically linked collagen- $\mathrm{TiO}_{2}$ facilitated epithelial cell stretching and sheet formation. Similarly, Bishal et al. [96] informed that collagen- $\mathrm{TiO}_{2}$ promotes human osteoblast growth and proliferation in a dose-dependent manner with no inflammatory response detected, which was associated with the ability of $\mathrm{TiO}_{2}$ to interact with calcium and phosphate elements, suggesting that this material could be used for applications in bone tissue engineering. On the other hand, Vedhanayagam et al. [97] informed that the poly(methyl methacrylate)-collagen-PdO- $\mathrm{TiO}_{2}$ hybrid scaffolds did not show toxic effects on MG 63 cells (human osteosarcoma), and enhanced the alkaline phosphatase activity during in vitro osteogenic differentiation by the secretion of the osteogenic protein, leading to bone formation. Moreover, the hybrid scaffold exhibited higher thermal stability $\left(83.45^{\circ} \mathrm{C}\right)$, and mechanical strength (Young's modulus $105.57 \mathrm{MPa}$ ) than the pure collagen scaffold $\left(71.64^{\circ} \mathrm{C}, 11.67 \mathrm{MPa}\right.$, respectively), due to the chemical and physical interaction between collagen and Palladium oxide ( $\mathrm{PdO})-\mathrm{TiO}_{2}$.

Additionally, collagen-silane- $\mathrm{TiO}_{2}$ has also been used as a functional agent of $\mathrm{Mg}$ alloys. The hybrid composite promotes the formation of a stable $\mathrm{Mg}(\mathrm{OH})_{2} / \mathrm{MgCO}_{3} / \mathrm{CaCO}_{3}$ structure that effectively protects its corrosion. Moreover, the collagen-silane- $\mathrm{TiO}_{2}$ improved osteoblasts and fibroblasts proliferation compared to bare and silane- $\mathrm{TiO}_{2}$-coated alloys. In the long term, collagen-silane- $\mathrm{TiO}_{2}$ is a viable strategy to prevent $\mathrm{Mg}$ alloy degradation due to the formation of a complex structure [93]. On the other hand, Li et al. [34] made 3D nanocomposite scaffolds composed of collagen, polyvinyl pyrrolidone (PVP), and $\mathrm{TiO}_{2}$ nanoparticles, with good degradation resistance in PVP dose-dependent response for potential tissue engineering applications. Likewise, collagen-chitosan- $\mathrm{TiO}_{2}$ scaffolds exhibited antimicrobial activity against $S$. aureus and improved permeability, stability to degradation, and cell aggregation to stop bleeding, which are suitable for the development of wound-healing materials [27].

Significant evidence shows that collagen functionalization with $\mathrm{TiO}_{2}$ nanoparticles improved its biological properties for dental implants and bone and dermal regeneration. 


\subsubsection{Other Applications of Collagen- $\mathrm{TiO}_{2}$ Hybrid Composite}

Other researched applications of the collagen- $\mathrm{TiO}_{2}$ hybrid composite include the development of packaging materials, catalysts, and electronics (Table 6). Erciyes et al. [98] proposed the use of leather solid wastes as a source of collagen hydrolyzed to make composites functionalized with $\mathrm{TiO}_{2}$. The hybrid film exhibited improved water vapor permeability, water-solubility, elongation at break, and tensile strength. The authors highlighted the potential reuse of collagen-waste to develop packaging materials.

Additionally, Luo et al. [99] informed that collagen- $\mathrm{TiO}_{2}: \mathrm{Tb}^{3+}$-doped hybrid material exhibited excellent photocatalytic performance against methyl orange $(93.87 \%)$ dye after $6 \mathrm{~h}$ of exposure in UV-light irradiation (150 W).

Furthermore, Cheng et al. [100] proposed a facile synthetic strategy to engineer a one-dimensional (1D) hierarchically ordered mesoporous $\mathrm{TiO}_{2}$ nanofiber bundles (TBs) by using low-cost natural collagen fibers as a bio-template. In general, the hybrid structure can offer shortened ion diffusion paths, ensuring an efficient electrolyte penetration for ion access without affecting its structural integrity. They conclude that the hybrid materials had excellent electrochemical lithium and sodium storage properties.

In general, the collagen- $\mathrm{TiO}_{2}$ hybrid material exhibited potential applications such as food and non-food packaging, environmental remediation, and electrochemical studies.

\subsection{Soy Protein- $-\mathrm{TiO}_{2}$ Hybrid Composite}

Soy protein isolate (SPI) is a by-product attained from the manufacture of soybean oil with a complex mixture of proteins ( $\beta$-conglycinin and glycinin) with a minimum protein content 0 $90 \%$ on a moisture-free basis [101,102]. It is readily available, biodegradable, and biocompatible for edible coatings [19] with potential usage on food packaging [72,103]. However, the main disadvantages of SPI-based films include weak mechanical properties and high sensitivity to humidity $[102,104]$. In that sense, SPI films have been functionalized with $\mathrm{TiO}_{2}$ to enhance their physical properties, where the most common method for its preparation is evaporative casting. Furthermore, the nanoparticles used are commercially available in its anatase phase, with concentrations ranging from $0.5 \%$ to $2 \%$ in weight of total solid content (Table 7). 
Table 7. Effect of $\mathrm{TiO}_{2}$ incorporation on soy protein isolate-based materials.

\begin{tabular}{|c|c|c|c|c|c|}
\hline Application & Method/Presentation & * Composition & $\mathrm{TiO}_{2}$ Specifications & Relevant Results & Ref. \\
\hline $\begin{array}{c}\text { Food } \\
\text { packaging }\end{array}$ & $\begin{array}{l}\text { Evaporative } \\
\text { casting/Films }\end{array}$ & 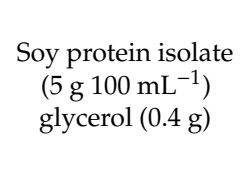 & $\begin{array}{l}\text { Commercial } \\
\left(\mathrm{TiO}_{2}\right): 1.5 \% w / v \\
\text { CP: Anatase }\end{array}$ & $\begin{array}{c}\mathrm{TiO}_{2} \text { improved the } \\
\text { physicochemical and } \\
\text { antimicrobial properties } \\
\text { of the soy protein } \\
\text { isolate film. }\end{array}$ & [101] \\
\hline $\begin{array}{c}\text { Food } \\
\text { packaging }\end{array}$ & $\begin{array}{l}\text { Evaporative } \\
\text { casting/Films }\end{array}$ & $\begin{array}{l}\text { Soy protein isolate } \\
\left(5 \mathrm{~g} 100 \mathrm{~mL}^{-1}\right), \\
\text { sorbitol }(20 \%) \\
\text { glycerol }(10 \%)\end{array}$ & $\begin{array}{c}\text { Commercial } \\
\left(\mathrm{TiO}_{2}\right): 2 \% w / w\end{array}$ & $\begin{array}{l}\text { The hybrid film } \\
\text { exhibited improved } \\
\text { mechanical properties. }\end{array}$ & [102] \\
\hline $\begin{array}{c}\text { Food } \\
\text { packaging }\end{array}$ & $\begin{array}{l}\text { Evaporative casting/ } \\
\text { Films }\end{array}$ & $\begin{array}{l}\text { Soy protein isolate } \\
(5 \%) \text {, glycerol }(2 \%),\end{array}$ & $\begin{array}{l}\text { Commercial } \\
\left(\mathrm{TiO}_{2}\right): 0.5 \% w / w \\
\text { Size: } 15-30 \mathrm{~nm} \\
\text { CP: Anatase }\end{array}$ & $\begin{array}{l}\mathrm{TiO}_{2} \text { improved the } \\
\text { physicochemical and } \\
\text { antimicrobial properties } \\
\text { of the soy protein } \\
\text { isolate film. }\end{array}$ & [19] \\
\hline $\begin{array}{c}\text { Food } \\
\text { packaging }\end{array}$ & $\begin{array}{l}\text { Evaporative } \\
\text { casting/Films }\end{array}$ & $\begin{array}{l}\text { Soy protein isolate } \\
\left(4.5 \mathrm{~g} 150 \mathrm{~mL}^{-1}\right) \\
\text { glycerol }(3.75 \mathrm{~g} \\
\left.150 \mathrm{~mL}^{-1}\right)\end{array}$ & $\left(\mathrm{TiO}_{2}\right): 1.33 \% w / w$ & $\begin{array}{c}\text { Hybrid composite } \\
\text { effectively extended the } \\
\text { shelf life of strawberries } \\
\text { and antimicrobial } \\
\text { activity. }\end{array}$ & [105] \\
\hline $\begin{array}{c}\text { Food } \\
\text { packaging }\end{array}$ & $\begin{array}{l}\text { Evaporative casting/ } \\
\text { Films }\end{array}$ & $\begin{array}{l}\text { Soy protein isolate } \\
\text { (NI) }\end{array}$ & $\left(\mathrm{TiO}_{2}\right): \mathrm{NI}$ & $\begin{array}{l}\text { Grapes treated with } \\
\text { hybrid films showed } \\
\text { higher quality } \\
\text { parameters than } \\
\text { uncoated fruits. }\end{array}$ & [106] \\
\hline $\begin{array}{l}\text { Food and } \\
\text { non-food } \\
\text { packaging }\end{array}$ & $\begin{array}{l}\text { Evaporative } \\
\text { casting/Films }\end{array}$ & $\begin{array}{l}\text { Soy protein isolate } \\
\left(4.5 \mathrm{~g} 150 \mathrm{~mL}^{-1}\right), \\
\text { glycerol }(2 \%)\end{array}$ & $\begin{array}{c}\text { Commercial } \\
\left(\mathrm{TiO}_{2}\right): 1.33 \% w / w \mathrm{TiO}_{2} \\
\text { with crystalline structure }\end{array}$ & $\begin{array}{l}\text { The hybrid composite } \\
\text { showed antimicrobial } \\
\text { activity. }\end{array}$ & [23] \\
\hline
\end{tabular}

\subsubsection{Food and Non-Food Packaging Applications of Collagen- $\mathrm{TiO}_{2}$ Hybrid Composite}

Table 7 lists the work on soy protein isolate- $\mathrm{TiO}_{2}$ hybrid material for food and non-food packaging development with enhanced properties. Malathi et al. [102] informed that $\mathrm{TiO}_{2}$ incorporation into an SPI film promotes an increase in thickness, opacity, tensile strength, and elongation at break of the cast film, which was associated with the hydrogen bonding or O-Ti-O bonding. Moreover, a strong charge and polar interaction between side chains of soy protein molecules restrict segment rotation and molecular mobility, leading to an increase in the elongation of the hybrid film. Furthermore, Lu et al. [101] reported that the functionalization of an SPI film with $\mathrm{TiO}_{2}$ promoted a decrease in water vapor (from 5.43 to $4.62 \mathrm{~g} \cdot \mathrm{mm} \cdot \mathrm{m}^{-2} \cdot \mathrm{day}^{-1} \cdot \mathrm{kPa}^{-1}$ ) and oxygen (from 0.470 to $0.110 \mathrm{~g} \cdot \mathrm{cm}^{-2} \cdot \mathrm{day}^{-1}$ ) permeability, as well as an increase in tensile strength (from 6.6683 to $14.5642 \mathrm{MPa}$ ) in a $\mathrm{TiO}_{2}$ concentration-dependent response. They argue that the presence of $\mathrm{TiO}_{2}$ in protein structure significantly changes the hydrophilic nature of the film, due to the stable covalent ( $\mathrm{Si}-\mathrm{O}-\mathrm{C}, \mathrm{Ti}-\mathrm{O}-\mathrm{C}$, and $\mathrm{Si}-\mathrm{O}-\mathrm{Ti})$ and non-covalent (hydrogen bonds and Van der Waals forces) interactions between $\mathrm{TiO}_{2}$ and SPI. Moreover, the hybrid film exhibited antimicrobial effects against $E$. coli (inhibition zone by agar test diffusion assay of $27.34 \mathrm{~mm}$ ). Wang et al. [23] demonstrated the bactericidal efficiency of an $\mathrm{SPI}-\mathrm{TiO}_{2}$ hybrid film under UV-light (at $365 \mathrm{~nm}$ during two hours) against $E$. coli (reduction of $71.01 \%$ of viable cells) and S. aureus (reduction of $88.94 \%$ of viable cells), which was associated with the synergistic antimicrobial effect between $\mathrm{TiO}_{2}$ and $\beta$-conglycinin and glycinin peptides present in the SPI [107].

Additionally, Wang et al. [19] informed that $\mathrm{TiO}_{2}$ incorporation in an SPI film positively influences its tensile strength $\left(90.79 \%\right.$ higher than control). On the other hand, the addition of nano- $\mathrm{TiO}_{2}$ reduced the flexibility (70.21\% less than control), and water vapor (65.67\% less than control), and oxygen ( $46.50 \%$ less than control) permeability in comparison with control groups. This was due to the strong hydrogen bonds formed between the two main components, which could prevent water and oxygen from diffusing through the films. The reduction in flexibility values could be associated with a collapse of the crystalline structure of the hybrid material by the formation of aggregates by an excess of $\mathrm{TiO}_{2}$. 
The reported application of SPI-TiO ${ }_{2}$ hybrid film includes fruit preservation and water-dye degradation. Zhang et al. [105] reported that $\mathrm{SPI}-\mathrm{TiO}_{2}$ hybrid film was effective to extend the shelf life of strawberries stored at $4{ }^{\circ} \mathrm{C}$ up to 8 days without significant weight losses $(<17.3 \%)$ and color changes with stable microbial quality in comparison with the uncoated fruits. Similar trends were reported in grapes coated with an $\mathrm{SPI}-\mathrm{TiO}_{2}$ hybrid film by Hoseiniyan et al. [95], who reported that coated grapes exhibited good performance during cold storage (31 days at $4{ }^{\circ} \mathrm{C}$ ) without significant effects in the total soluble solids, titratable acidity, and weight losses. The hybrid film prevents the fungal infection of the fruits, and the coated fruits also had a good appearance and marketability compared with the uncoated fruits.

In summary, the incorporation of $\mathrm{TiO}_{2}$ into SPI significantly improved its physicochemical properties and exhibited good fruit preservation performance.

\subsubsection{Other Applications of Soy Protein Isolate- $\mathrm{TiO}_{2}$ Hybrid Composite}

Calza et al. [108] fabricated a system composed of soybean peroxidase and $\mathrm{TiO}_{2}$ nanoparticles for environmental remediation purposes (Table 7). They informed that the hybrid material effectively remove orange II dye (100\%) and carbamazepine $(100 \%)$ drug from aqueous solutions after $60 \mathrm{~min}$ of exposure compared with the soybean peroxidase structure $(<80 \%$ and $<10 \%$, respectively, after $120 \mathrm{~min}$ of exposure), which was associated with the synergistic properties of peroxidase and $\mathrm{TiO}_{2}$. Further studies are needed to understand the removal and degradation mechanism of soybean peroxidase- $\mathrm{TiO}_{2}$, which could be used as an alternative for wastewater treatment.

\subsection{Other Proteins Functionalized with $\mathrm{TiO}_{2}$}

Table 8 lists various non-conventional proteins functionalized with $\mathrm{TiO}_{2}$, such as zein, keratin, sodium caseinate, lactoferrin, and sesame, to enhance their physicochemical properties, where the most common method for their preparation is evaporative casting for films and freeze-drying for hydrogels and scaffolds. Furthermore, the nanoparticles used are commercially available with sizes ranging from 10 to $200 \mathrm{~nm}$ in its anatase phase, and in some cases in its rutile phase, using concentrations ranging from $0.5 \%$ to $10 \%$ in weight of total solid content.

Table 8. Effect of $\mathrm{TiO}_{2}$ incorporation on non-conventional protein-based materials.

\begin{tabular}{|c|c|c|c|c|c|}
\hline Application & Method/Presentation & * Composition & $\mathrm{TiO}_{2}$ Specifications & Relevant Results & Ref. \\
\hline $\begin{array}{l}\text { Food and } \\
\text { non-food } \\
\text { packaging }\end{array}$ & $\begin{array}{l}\text { Evaporative } \\
\text { casting/Film }\end{array}$ & $\begin{array}{l}\text { Zein }(13.5 \% w / v) \\
\text { glycerol:PEG } 600 \\
\quad(3.3 \% w / w)\end{array}$ & $\begin{array}{c}\text { Commercial } \\
\mathrm{SM}^{\text {M Hydrothermal }} \\
\left(\mathrm{TiO}_{2}: \mathrm{SiO}_{2}\right): 1.5 \% \mathrm{w} / \mathrm{v} \\
\text { Size: } 100-180 \mathrm{~nm}\end{array}$ & $\begin{array}{l}\mathrm{TiO}_{2} \text { improved the } \\
\text { mechanical, thermal, } \\
\text { and water-related } \\
\text { properties of zein film. }\end{array}$ & [24] \\
\hline $\begin{array}{c}\text { Food } \\
\text { packaging }\end{array}$ & $\begin{array}{c}\text { Evaporative } \\
\text { casting/Nanofibers }\end{array}$ & $\begin{array}{c}\text { Zein }\left(3 \mathrm{~g} 10 \mathrm{~mL}^{-1} \text { of }\right. \\
70 \% \text { aqueous } \\
\text { ethanol })\end{array}$ & $\begin{array}{c}\text { Commercial } \\
\left(\mathrm{TiO}_{2}: \mathrm{SiO}_{2}\right): 5 \% w / w \\
\text { Size: }<25 \mathrm{~nm} \\
\text { CP: Anatase } \\
\text { Purity: } 99.7 \%\end{array}$ & $\begin{array}{l}\text { Coated fruits extend } \\
\text { their shelf life. }\end{array}$ & [33] \\
\hline $\begin{array}{l}\text { Food and } \\
\text { non-food } \\
\text { packaging }\end{array}$ & $\begin{array}{l}\text { Evaporative } \\
\text { casting/Film }\end{array}$ & $\begin{array}{l}\text { Zein: sodium } \\
\text { alginate }(90: 10), \\
\text { betanin }(1 \%)\end{array}$ & $\begin{array}{l}\text { Commercial } \\
\left(\mathrm{TiO}_{2}\right): 0.5 \% w / w \\
\text { Size: } 10-25 \mathrm{~nm}\end{array}$ & $\begin{array}{l}\text { The hybrid film } \\
\text { exhibited antimicrobial } \\
\text { activity. }\end{array}$ & [109] \\
\hline $\begin{array}{l}\text { Food and } \\
\text { non-food } \\
\text { packaging }\end{array}$ & $\begin{array}{l}\text { Evaporative } \\
\text { casting/Film }\end{array}$ & $\begin{array}{l}\text { Sodium caseinate } \\
\left(8 \mathrm{~g} 100 \mathrm{~mL}^{-1}\right) \text {, guar } \\
\operatorname{gum}(0.3 \% w / w) \\
\operatorname{CEO}(2 \% w / w)\end{array}$ & $\begin{array}{l}\text { Commercial } \\
\left(\mathrm{TiO}_{2}\right): 1 \% w / w \\
\text { Size: } 10-25 \mathrm{~nm} \\
\text { CP: Anatase } \\
\text { Purity: }>99 \%\end{array}$ & $\begin{array}{l}\text { The hybrid film } \\
\text { exhibited antimicrobial } \\
\text { activity. }\end{array}$ & [11] \\
\hline $\begin{array}{l}\text { Food and } \\
\text { non-food } \\
\text { packaging }\end{array}$ & $\begin{array}{l}\text { Evaporative } \\
\text { casting/Film }\end{array}$ & $\begin{array}{c}\text { Sodium caseinate } \\
(2.5 \% w / w), \text { glycerol } \\
(2 \% w / w)\end{array}$ & $\begin{array}{l}\text { Commercial (P25) } \\
\left(\mathrm{TiO}_{2}\right): 0.5 \% w / w\end{array}$ & $\begin{array}{l}\mathrm{TiO}_{2} \text { improved the } \\
\text { mechanical, thermal, } \\
\text { and water-related } \\
\text { properties of the film. }\end{array}$ & [30] \\
\hline
\end{tabular}


Table 8. Cont.

\begin{tabular}{|c|c|c|c|c|c|}
\hline Application & Method/Presentation & * Composition & $\mathrm{TiO}_{2}$ Specifications & Relevant Results & Ref. \\
\hline $\begin{array}{l}\text { Food and } \\
\text { non-food } \\
\text { Packaging }\end{array}$ & $\begin{array}{l}\text { Evaporative } \\
\text { casting/Films }\end{array}$ & $\begin{array}{c}\text { Feather keratin } \\
(1.2 \mathrm{~g}), \text { PVA }(13.33 \mathrm{~g})\end{array}$ & $\begin{array}{l}\text { Commercial (P25) } \\
\left(\mathrm{TiO}_{2}\right): 3 \% w / w \\
\text { Size: } 60 \mathrm{~nm} \\
\text { CP: Anatase } \\
\text { Purity: } 99.8 \%\end{array}$ & $\begin{array}{l}\text { The hybrid material } \\
\text { exhibited improved } \\
\text { physicochemical } \\
\text { properties. }\end{array}$ & [110] \\
\hline $\begin{array}{l}\text { Food and } \\
\text { non-food } \\
\text { Packaging }\end{array}$ & $\begin{array}{c}\text { Catalyst } \\
\text { curing/Composite }\end{array}$ & $\begin{array}{c}\text { Raw wool keratin } \\
\left(350 \mathrm{~g} / \mathrm{m}^{2}\right), \text { BTCA } \\
(12.6 \%)\end{array}$ & $\begin{array}{l}\text { Commercial }(\mathrm{P} 25) \\
\left(\mathrm{TiO}_{2}\right): 0.6 \mathrm{~g} \cdot \mathrm{L}^{-1} \\
\text { Size: } 21 \mathrm{~nm} \\
\text { CP: Anatase-Rutile } \\
\text { Crystalline structure }\end{array}$ & $\begin{array}{l}\text { The hybrid material } \\
\text { showed an improved } \\
\text { UV-protective effect. }\end{array}$ & [22] \\
\hline $\begin{array}{l}\text { Environmental } \\
\text { remediation }\end{array}$ & $\begin{array}{l}\text { Evaporative } \\
\text { casting/Film }\end{array}$ & $\begin{array}{l}\text { Sesame protein }(3 \mathrm{~g} \\
\left.100 \mathrm{~mL}^{-1}\right) \text {, glycerol } \\
(30 \% \text { in total solid } \\
\text { content })\end{array}$ & $\begin{array}{l}\text { Commercial (P25) } \\
\left(\mathrm{TiO}_{2}\right): 3 \% w / w \\
\text { Size: } 21 \mathrm{~nm} \\
\text { CP: Anatase-Rutile } \\
\text { Crystalline structure }\end{array}$ & $\begin{array}{l}\text { The hybrid film } \\
\text { exhibited photocatalytic } \\
\text { activity against } \\
\text { methylene blue. }\end{array}$ & [16] \\
\hline $\begin{array}{l}\text { Environmental } \\
\text { remediation }\end{array}$ & $\begin{array}{l}\text { Electrospinning/ } \\
\text { Nanofibers }\end{array}$ & $\begin{array}{l}\text { Keratin-PLA- } \mathrm{TiO}_{2} \\
\text { mass ratio of } 33: 33: 33\end{array}$ & $\begin{array}{l}\text { Commercial (P25) } \\
\text { CP: Anatase }\end{array}$ & $\begin{array}{l}\text { The hybrid nanofibers } \\
\text { effectively remove } \\
\text { methylene blue dye from } \\
\text { the aqueous solution. }\end{array}$ & [112] \\
\hline $\begin{array}{l}\text { Environmental } \\
\text { remediation }\end{array}$ & Biometic/Microspheres & NI & Anatase & $\begin{array}{c}\text { The hybrid composite } \\
\text { showed good } \\
\text { photocatalytic properties } \\
\text { again or dye yellow and } \\
\text { blue acid dyes. }\end{array}$ & [113] \\
\hline Biomedical & Dip-coating/Coating & $\begin{array}{l}\text { Lactoferrin } \\
\left(0.2 \mathrm{mg} \cdot \mathrm{mL}^{-1}\right) \\
\text { collagen } \\
\left(0.2 \mathrm{mg} \cdot \mathrm{mL}^{-1}\right)\end{array}$ & $\begin{array}{c}\text { SM: Sol-gel } \\
\left(\mathrm{TiO}_{2}\right): \mathrm{NI} \\
\text { Size: } 200 \mathrm{~nm} \\
\mathrm{CP}: \text { Anatase } \\
\text { Crystalline structure }\end{array}$ & $\begin{array}{c}\text { The hybrid coating } \\
\text { showed enhanced } \\
\text { biocompatibility with } \\
\text { MG-6e cells. }\end{array}$ & [116] \\
\hline
\end{tabular}

* Material composition was based on the best-reported results. NI: No information; CEO: cumin essential oil; PVA: polyvinyl alcohol; PEG: polyethylene glycol; BTCA: 1,2,3,4-butane tetracarboxylic acid; PLA: poly(Lactic acid); SM: synthesis method; $\left(\mathrm{TiO}_{2}\right)$ : concentration of titanium dioxide; $\mathrm{CP}$ : crystallite phase.

\subsubsection{Packaging Applications of Non-Conventional Proteins Functionalized with $\mathrm{TiO}_{2}$}

Table 8 lists reports on the use of non-conventional protein materials functionalized with $\mathrm{TiO}_{2}$ for food and non-food packaging development. Kadam et al. [24] evaluated the effect of $\mathrm{TiO}_{2}: \mathrm{SiO}_{2}$ nanoparticles incorporation on the thermal and mechanical properties of a cast zein film. They reported that mechanical properties (tensile strength) of the hybrid film were enhanced; however, its flexibility was reduced two-fold compared with zein film, possibly associated with the formation of $\mathrm{TiO}_{2}$ aggregates. Furthermore, the water contact angle, water vapor permeability, and thermal properties of the hybrid film were improved by the addition of inorganic nanoparticles, associated with the interaction between zein and $\mathrm{TiO}_{2}: \mathrm{SiO}_{2}$, which promotes a stable and strong hydrogen bonds formation. Similarly, Amjadi et al. [109] made zein-sodium alginate (90:10) film functionalized with $\mathrm{TiO}_{2}$-betanin (0.5\%:1\%) nanoparticles and informed that the hybrid film exhibited antioxidant properties (by the presence of bioactive compounds in betanin) and high antimicrobial effects (by agar test diffusion assay) against $E$. coli (15.4 $\mathrm{mm}$ of inhibition zone) and S. aureus (16.9 $\mathrm{mm}$ of inhibition zone), which was 
attributed to the antimicrobial properties of $\mathrm{TiO}_{2}$. Moreover, Böhmer-Maas et al. [33] developed a zein- $\mathrm{TiO}_{2}$ nanofiber as an ethylene absorber for cherry tomatoes preservation $\left(25^{\circ} \mathrm{C}\right)$. They reported that coated fruits with the hybrid film exhibited less ethylene concentration $\left(9.38 \mu \mathrm{g} \cdot \mathrm{L}^{-1} \cdot \mathrm{g}^{-1} \cdot \mathrm{h}^{-1}\right)$ than those coated with a zein film $\left(10.27 \mu \mathrm{g} \cdot \mathrm{L}^{-1} \cdot \mathrm{g}^{-1} \cdot \mathrm{h}^{-1}\right)$, which permits extended the shelf life of cherry tomatoes up to 22 days. According to the authors, the ethylene degradation occurs by the oxidation of ethylene into $\mathrm{CO}_{2}$ and water by the $\mathrm{OH}$ radicals and reactive oxygen species generated by the photocatalytic ability of $\mathrm{TiO}_{2}$.

Montes-de-Oca-Ávalos et al. [30] investigated the effect of $\mathrm{TiO}_{2}$ incorporation on the physicochemical properties of a sodium caseinate film. They informed that mechanical, thermal, water vapor permeability characteristics of the caseinate film were improved in $\mathrm{TiO}_{2}$ concentration-dependent way, associated with good dispersion of $\mathrm{TiO}_{2}$ through the film polymeric matrix. According to the authors, the presence of $\mathrm{TiO}_{2}$ avoids protein agglomeration due to the stable hydrogen bond formation. Additionally, Alizadeh-Sani et al. [11] informed that a sodium caseinate-guar gum film functionalized with $\mathrm{TiO}_{2}(1 \% w / w)$ and cumin essential oil $(2 \% w / w)$ showed remarkable antimicrobial activity against L. monocytogenes (16 mm of inhibition zone), S. aureus (15 mm of inhibition zone), E. coli O157:H7 (14 mm of inhibition zone), S. enteritidis (12 $\mathrm{mm}$ of inhibition zone) in a strain-dependent manner. These results were associated with the cell wall differences between bacteria (outer membrane) and the synergistic antimicrobial effect among $\mathrm{TiO}_{2}$ and cumin essential oil. Moreover, the water vapor permeability, tensile strength, and flexibility of the combined film were improved by a synergistic effect of $\mathrm{TiO}_{2}$ and cumin essential oil.

Additionally, Montazer et al. [22] informed that the incorporation of $\mathrm{TiO}_{2}$ in a wool keratin film stabilized by butane tetracarboxylic acid (BTCA) exhibited excellent UV-barrier properties related to the $\mathrm{C}-\mathrm{N}$ and $\mathrm{N}-\mathrm{H}$ bonds promoted for $\mathrm{TiO}_{2}$ and $\mathrm{BTCA}$ interactions, with an optimum concentration of $0.6 \mathrm{~g} \cdot \mathrm{L}^{-1}$ and $12.94 \% w / v$. Similarly, Wu et al. [110], who informed that thermal stability, mechanical resistance, and water vapor permeability of the keratin-tris film were improved by its functionalization with $\mathrm{TiO}_{2}$ that may act as a physical cross-linker agent.

According to evidence, functionalization of non-conventional proteins like zein, keratin, and sodium caseinate with $\mathrm{TiO}_{2}$ nanoparticles exhibited interesting properties for food and non-food packaging development.

\subsubsection{Environmental Applications of Non-Conventional Proteins Functionalized with $\mathrm{TiO}_{2}$}

Usage of zein, keratin, and sesame proteins as a supporting material of $\mathrm{TiO}_{2}$ for the removal and degradation of water pollutants have been explored (Table 8). Babitha and Korrapati [113] made mesoporous microspheres formed by zein and $\mathrm{TiO}_{2}$ as an alternative for acid yellow (AY110) and acid blue (AB113) dyes decolorization under UV-light irradiation. They reported that the hybrid microspheres $\left(1 \mathrm{mg} \cdot \mathrm{mL}^{-1}\right)$ showed a dye removal efficiency of $96 \%$ and $89 \%$ in AY110 and AB113, respectively, at lower dye concentration $\left(10 \mathrm{mg} \cdot \mathrm{L}^{-1}\right)$ but decreased at higher concentrations $\left(100 \mathrm{mg} \cdot \mathrm{L}^{-1}\right)$, which was associated with the saturation of active sites into the hybrid matrix.

Additionally, Villanueva et al. [111] fabricated a hydrogel combining keratin (from cow's horn) and $\mathrm{TiO}_{2}$ to remove trimethoprim from wastewater. They reported that the hybrid material exhibited good degradation efficiency ( $>95 \%$ ) against antibiotic removal from aqueous solution in a $\mathrm{TiO}_{2}$ dose-dependent response, with an optimum $\mathrm{TiO}_{2}$ concentration of $10 \% w / w$ with performance up to four consecutive cycles (90\%). It was associated with the swelling and adsorptive abilities of the hybrid film and to the presence of active sites on the catalyst surface due to the strong attachment between keratin and $\mathrm{TiO}_{2}$ through covalent and non-covalent interactions. Moreover, Siriorn and Jatuphorn [112] reported that a chicken feather keratin-poly(lactic acid)- $\mathrm{TiO}_{2}$ nanofibers $(0.05 \mathrm{~g})$ effectively remove methylene blue $(90 \%)$ dye from aqueous solution $\left(5 \times 10^{-6} \mathrm{M}\right)$ under visible light due to the improved adsorptive properties of the hybrid nanofibers.

Fathi et al. [16] made a sesame protein isolate film functionalized with $\mathrm{TiO}_{2}$ for water-dye removal purposes. They reported that the hybrid film $\left(64 \mathrm{~cm}^{2}\right)$ effectively degraded $76 \%$ of methylene blue dye 
(10 mg. $\left.\mathrm{mL}^{-1}\right)$ under UV-light irradiation after $120 \mathrm{~min}$ of exposure. Moreover, the hybrid material exhibited enhanced water vapor permeability, water resistance, water contact angle, and mechanical strength in a $\mathrm{TiO}_{2}$ dose-dependent response with an optimum $\mathrm{TiO}_{2}$ concentration of $3 \% w / w$ associated with the interaction chemical and physical interactions between sesame protein and $\mathrm{TiO}_{2}$. On the other hand, the morphological studies through scanning electron microscopy revealed that a high concentration of $\mathrm{TiO}_{2}$ exhibited an inhomogeneous dispersion, causing aggregations in the protein matrix that negatively affects its functionality.

To summarize, non-conventional proteins like zein, keratin, and sesame functionalized with $\mathrm{TiO}_{2}$ nanoparticles could be a viable, low-cost, and efficient alternative for environmental applications as photocatalysts for wastewater treatment.

\subsubsection{Other Applications of Non-Conventional Proteins Functionalized with $\mathrm{TiO}_{2}$}

Other potential uses of non-conventional proteins functionalized with $\mathrm{TiO}_{2}$ include bone regeneration, antimicrobial activity, and textiles (Table 8). Johari et al. [114] made a fluorated silk fibroin- $\mathrm{TiO}_{2}$ hybrid scaffold for bone tissue engineering with non-toxic effects in human osteoblast cells (SaOS-2) and suitable cell attachment and spreading on the hybrid material, which was associated with the fluoridation of $\mathrm{TiO}_{2}$ nanoparticles $\left(\mathrm{TiO}_{2}-\mathrm{F}\right)$. Moreover, the hybrid scaffold exhibited good porosity (200 to $500 \mu \mathrm{m}$ ), mechanical resistance (tensile strength of $1.7 \mathrm{MPa}$ ), and adequate biodegradation rate (from $1 \%$ to $5 \%$ of weight loss in 30 days) in a $\mathrm{TiO}_{2}$ dose-dependent response due to the formation of $\mathrm{Ti}-\mathrm{O}-\mathrm{C}$ bonds and the partial substitution of $\mathrm{OH}$ groups present in the $\mathrm{TiO}_{2}$ surface by fluorine anions, that significantly increase the functional properties of $\mathrm{TiO}_{2}$. On the other hand, with high amounts of $\mathrm{TiO}_{2}(>15 \%)$, some agglomerates could appear that negatively affect the technological properties of the hybrid scaffold.

Mehrabani et al. [115] informed that a chitin-fibroin- $\mathrm{TiO}_{2}$ hybrid composite did not show cytotoxic effects on a human Caucasian fetal foreskin fibroblast cell line at low $\mathrm{TiO}_{2}$ concentrations $(<1.5 \% w / w)$. Nonetheless, the hybrid material exhibited a porosity of $94 \%$, a density of $3118 \mathrm{mg} \cdot \mathrm{mL}^{-1}$, and water resistance with a swelling degree of $93 \%$ after $24 \mathrm{~h}$. In addition, it showed antimicrobial properties against E. coli, S. aureus, and C. albicans, which are suitable for the development of wound-healing materials. According to Feng et al. [117], incorporation of $\mathrm{TiO}_{2}$ into fibroin (mostly $\alpha$-helix) matrix promotes structural changes that permit a strong interaction with the $\beta$-sheets changing from typical silk I to Silk II structure in a $\mathrm{TiO}_{2}$-dependent manner, attributed to the presence of hydroxyl groups on the $\mathrm{TiO}_{2}$. The enhanced properties of fibroin could be related to the conformational structure. On the other hand, the authors reported that a high concentration of $\mathrm{TiO}_{2}$ might negatively affect the mechanical properties of the hybrid material associated with the damage of its microscopic structure mainly by the formation of $\mathrm{TiO}_{2}$ agglomerates, and possibly to the extra water used for the preparation of the hybrid material.

Kazek-Kesik et al. [116] coated a lactoferrin-collagen composite on titanium alloys for bone replacement. It was found that the presence of lactoferrin and $\mathrm{TiO}_{2}$ enhanced osteoblast-like effect on MG-63 cells after seven days of evaluation in comparison with collagen-treated cells, mainly by the ability of both components to promote cell adhesion.

According to the evidence, the functionalization of non-conventional proteins with $\mathrm{TiO}_{2}$ nanoparticles exhibited interesting properties and applications. However, further studies are needed to validate their potential uses.

\section{Disadvantages of Protein- $\mathrm{TiO}_{2}$ Hybrid Composites and Perspectives}

Despite the observation that protein- $\mathrm{TiO}_{2}$ hybrid composites exhibited excellent technological and functional properties with great potential to be used in several applications, it is necessary to evaluate the safe use and implementation of this kind of hybrid composites, mainly due to the presence of $\mathrm{TiO}_{2}$ in their composition. 
In this context, it has been reported that pure $\mathrm{TiO}_{2}$ exhibited toxicological and adverse effects in cell lines (HeLa and HaCaT), proteins (microtubule and bovine serum albumin), and animal models (Sprague-Dawley rats, Wistar rats, and mussel Mytilus coruscus) in a concentration-dependent response, typically at doses ranging from 0.4 to $100 \mathrm{mg} \cdot \mathrm{mL}^{-1}$ with direct application [118-123]. Nonetheless, the tested concentrations of $\mathrm{TiO}_{2}$ in these works were higher than the recommended safe usage ( $<1 \%$ by weight) by international regulations in the use of $\mathrm{TiO}_{2}$ as a food additive [124].

However, the amount of $\mathrm{TiO}_{2}$ used as a functional agent to develop protein- $\mathrm{TiO}_{2}$ hybrid composites ranges from 0.003 to $1 \mathrm{mg} \cdot \mathrm{mL}^{-1}$, depending on its application. For example: in food packaging materials manufacturing, the amount average of $\mathrm{TiO}_{2}$ employed is $0.28 \mathrm{mg} \cdot \mathrm{mL}^{-1}$, while for packaging materials with non-food purposes it is $0.85 \mathrm{mg} \cdot \mathrm{mL}^{-1}$. Moreover, for the development of scaffolds, dental implants, and wound-healing materials, the average amount of $\mathrm{TiO}_{2}$ is 0.23 and $0.9 \mathrm{mg} \cdot \mathrm{mL}^{-1}$ for making hybrid materials for environmental remediation.

According to $\mathrm{Xu}$ et al. (2017) [123], the interaction between protein structure and $\mathrm{TiO}_{2}$ plays a critical role in the safe use of these materials, which usually depends on the new properties of each hybrid composite and the used concentration of $\mathrm{TiO}_{2}$ [125]. In this sense, there are a few reports on the toxicity status of protein- $\mathrm{TiO}_{2}$ hybrid composites, which reported no toxicological or adverse effects on their use, associated with the low concentration of $\mathrm{TiO}_{2}$ used for the functionalization of protein-based materials. However, most of the published reports cited in this document focused on in vitro evaluations. Therefore, further studies are needed to evaluate the possible human health and environmental risks on the usage of these hybrid composites.

\section{Concluding Remarks}

Significant evidence indicates that functionalization of protein-based materials by adding $\mathrm{TiO}_{2}$ nanoparticles is a feasible approach to improve their thermal, mechanical, optical, water-resistance, gas-barrier, and adsorptive properties. The evaporative casting method is one of the most common procedures for the preparation of protein- $\mathrm{TiO}_{2}$ hybrid films and coating and freeze-drying for hydrogels and scaffolds, using commercial $\mathrm{TiO}_{2}$ with a particle size ranging from 10 to $200 \mathrm{~nm}$ (the most frequently used is $10-25 \mathrm{~nm}$ in size) in its anatase phase with a crystalline structure.

Protein- $\mathrm{TiO}_{2}$ hybrid composites are an active research area for developing eco-friendly and active food and non-food packaging materials with antimicrobial and UV-protective effects. Furthermore, they are attractive and biocompatible materials to fabricate wound-healing patches, tissue engineering scaffolds, or biosensors for biomedical applications.

On the other hand, although the functionalization of protein-based materials with $\mathrm{TiO}_{2}$ offers significant advantages, some limitations have been reported, especially those associated with the concentration of $\mathrm{TiO}_{2}$. Higher concentrations of $\mathrm{TiO}_{2}$ could promote an inhomogeneous dispersion through the polymeric matrix, forming agglomerates that negatively affected the technological and functional properties of the hybrid material, particularly in flexibility and transparency. Likewise, the preparation method could negatively influence the properties of the hybrid material, associated with the physical and chemical interactions between components. For example, if there was no proper mixing ratio between protein and $\mathrm{TiO}_{2}$, a saturation of the available functional groups in the polymeric matrix can affect the physicochemical properties of the film. Additionally, other possible limitations of the protein- $\mathrm{TiO}_{2}$ hybrid composites could be related to the type and source of protein and its possible structural changes by the presence of $\mathrm{TiO}_{2}$ and its stability for diverse applications.

There are some challenges to be achieved for industrial applications; one of the most important is to obtain the correct amounts of protein and $\mathrm{TiO}_{2}$ nanoparticles because different uses require different formulations with desirable properties. For example, the shelf life of climacteric fruits depends on the correct exchange of oxygen, carbon dioxide, and water vapor permeability. Meanwhile, products with high amounts of lipids require UV-protective effects to prevent their oxidation. On the other hand, wound-healing materials should exhibit high water and mechanical resistance but correct gas exchange, high adherence, and antimicrobial properties. Moreover, standardized protocols for their preparation 
are needed for industrial-scale implementation. It is also necessary to carry out in vivo tests to evaluate the possible human health and environmental risks on the usage and safe implementation of these hybrid composites in diverse applications. Therefore, further research efforts should be dedicated to solving these challenges.

Author Contributions: Conceptualization, L.M.A.-E., Z.V.-d.1.M., D.A.L.-d.1.M., A.P.-L., and E.M.G.; methodology, L.M.A.-E., Z.V.-d.1.M., N.R.-B., T.S.-C., K.N., D.A.L.-d.1.M, A.P.-L., and E.M.-G.; investigation, L.M.A.-E., Z.V.-d.1.M., N.R.-B., T.S.-C., K.N., D.A.L.-d.1.M., A.P.-L., and E.M.-G.; writing-original draft preparation, L.M.A.-E., Z.V.-d.l.M., N.R.-B., T.S.-C., K.N., D.A.L.-d.1.M., A.P.-L., and E.M.-G.; writing-review and editing, L.M.A.-E., Z.V.-d.l.M., D.A.L.-d.1.M., A.P.-L., and E.M.-G.; supervision, L.M.A.-E., Z.V.-d.1.M., D.A.L.-d.1.M., A.P.-L., and E.M.-G. All authors have read and agreed to the published version of the manuscript.

Funding: This research received no external funding.

Acknowledgments: The authors gratefully acknowledge the financial support from a scholarship (702634) from CONACYT-Mexico, as well as Acoyani Garrido-Sandoval for proofreading the English language of this research.

Conflicts of Interest: The authors declare no conflict of interest.

\section{References}

1. Riahi, Z.; Priyadarshi, R.; Rhim, J.; Bagheri, R. Gelatin-based functional films integrated with grapefruit seed extract and $\mathrm{TiO}_{2}$ for active food packaging applications. Food Hydrocoll. 2021, 112, 106314. [CrossRef]

2. Avramescu, S.M.; Butean, C.; Popa, C.V.; Ortan, A.; Moraru, I.; Temocico, G. Edible and functionalized films/coatings-performances and perspectives. Coatings 2020, 10, 687. [CrossRef]

3. Lin, D.; Yang, Y.; Wang, J.; Yan, W.; Wu, Z.; Chen, H.; Zhang, Q.; Wu, D.; Qin, W.; Tu, Z. Preparation and characterization of $\mathrm{TiO}_{2}-\mathrm{Ag}$ loaded fish gelatin-chitosan antibacterial composite film for food packaging. Int. J. Biol. Macromol. 2020, 154, 123-133. [CrossRef] [PubMed]

4. El-wakil, N.A.; Hassan, E.A.; Abou-zeid, R.E.; Dufresne, A. Development of wheat gluten/nanocellulose/ titanium dioxide nanocomposites for active food packaging. Carbohydr. Polym. 2015, 124, 337-346. [CrossRef] [PubMed]

5. Park, J.E.; Park, I.; Neupane, M.P.; Bae, T.; Lee, M. Effects of a carbon nanotube-collagen coating on a titanium surface on osteoblast growth. Appl. Surf. Sci. 2014, 292, 828-836. [CrossRef]

6. Al Zoubi, W.; Kamil, M.P.; Fatimah, S.; Nisa, N.; Ko, Y.G. Recent advances in hybrid organic-inorganic materials with spatial architecture for state-of-the-art applications. Prog. Mater. Sci. 2020, 112, 100663. [CrossRef]

7. Zhao, Y.; Liu, J.; Zhang, M.; He, J.; Zheng, B.; Liu, F.; Zhao, Z.; Liu, Y. Use of silver nanoparticle-gelatin/alginate scaffold. Coatings 2020, 10, 948. [CrossRef]

8. Anaya-Esparza, L.M.; Villagrán-de la Mora, Z.; Ruvalcaba-Gómez, J.M.; Romero-Toledo, R.; SandovalContreras, T.; Aguilera-Aguirre, S.; Montalvo-González, E.; Pérez-Larios, A. Use of titanium dioxide $\left(\mathrm{TiO}_{2}\right)$ nanoparticles as reinforcement agent of polysaccharide-based materials. Processes 2020, 8, 1395. [CrossRef]

9. Anaya-Esparza, L.M.; Ruvalcaba-Gómez, J.M.; Maytorena-Verdugo, C.I.; González-Silva, N.; RomeroToledo, R.; Aguilera-Aguirre, S.; Pérez-Larios, A.; Montalvo-González, E. Chitosan- $\mathrm{TiO}_{2}$ : A versatile hybrid composite. Materials 2020, 13, 811. [CrossRef]

10. Omar, N.; Selvami, S.; Kaisho, M.; Yamada, M.; Yasui, T.; Fukumoto, M. Deposition of titanium dioxide coating by the cold-spray process on annealed stainless steel substrate. Coatings 2020, 10, 991. [CrossRef]

11. Alizadeh-Sani, M.; Rhim, J.W.; Azizi-Lalabadi, M.; Hemmati-Dinarvand, M.; Ehsani, A. Preparation and characterization of functional sodium caseinate/guar gum $/ \mathrm{TiO}_{2} /$ cumin essential oil composite film. Int. J. Biol. Macromol. 2020, 145, 835-844. [CrossRef] [PubMed]

12. de Fonseca, J.M.; Valencia, G.A.; Soares, L.S.; Dotto, M.E.R.; Campos, C.E.M.; de Moreira, R.F.P.M.; Fritz, A.R.M. Hydroxypropyl methylcellulose- $\mathrm{TiO}_{2}$ and gelatin- $\mathrm{TiO}_{2}$ nanocomposite films: Physicochemical and structural properties. Int. J. Biol. Macromol. 2020, 151, 944-956. [CrossRef] [PubMed]

13. Anaya-Esparza, L.M.; Montalvo-González, E.; González-Silva, N.; Méndez-Robles, M.D.; Romero-Toledo, R.; Yahia, E.M.; Pérez-Larios, A. Synthesis and characterization of $\mathrm{TiO}_{2}-\mathrm{ZnO}-\mathrm{MgO}$ mixed oxide and their antibacterial activity. Materials 2019, 12, 698. [CrossRef] [PubMed] 
14. Anaya-Esparza, L.M.; González-Silva, N.; Yahia, E.M.; González-Vargas, O.A.; Montalvo-González, E.; Pérez-Larios, A. Effect of $\mathrm{TiO}_{2}-\mathrm{ZnO}-\mathrm{MgO}$ mixed oxide on microbial growth and toxicity against Artemia salina. Nanomaterials 2019, 9, 992. [CrossRef] [PubMed]

15. Ortelli, S.; Costa, A.L. Insulating thermal and water-resistant hybrid coating for fabrics. Coatings 2020, 10, 72. [CrossRef]

16. Fathi, N.; Almasi, H.; Pirouzifard, M.K. Sesame protein isolate based bionanocomposite films incorporated with $\mathrm{TiO}_{2}$ nanoparticles: Study on morphological, physical and photocatalytic properties. Polym. Test. 2019, 77, 105919. [CrossRef]

17. Li, Y.; Jiang, Y.; Liu, F.; Ren, F.; Zhao, G.; Leng, X. Fabrication and characterization of $\mathrm{TiO}_{2} /$ whey protein isolate nanocomposite film. Food Hydrocoll. 2011, 25, 1098-1104. [CrossRef]

18. Farshchi, E.; Pirsa, S.; Roufegarinejad, L.; Alizadeh, M.; Rezazad, M. Photocatalytic/biodegradable film based on carboxymethyl cellulose, modified by gelatin and $\mathrm{TiO}_{2}-\mathrm{Ag}$ nanoparticles. Carbohydr. Polym. 2019, 216, 189-196. [CrossRef]

19. Wang, Z.; Zhang, N.; Wang, H.Y.; Sui, S.Y.; Sun, X.X.; Ma, Z.S. The effects of ultrasonic/microwave assisted treatment on the properties of soy protein isolate/titanium dioxide films. LWT-Food Sci. Technol. 2014, 57, 548-555. [CrossRef]

20. Boughriba, S.; Souissi, N.; Jridi, M.; Li, S.; Nasri, M. Thermal, mechanical and microstructural characterization and antioxidant potential of Rhinobatos cemiculus gelatin films supplemented by titanium dioxide doped silver nanoparticles. Food Hydrocoll. 2020, 103, 105695. [CrossRef]

21. Vejdan, A.; Ojagh, S.M.; Adeli, A.; Abdollahi, M. Effect of $\mathrm{TiO}_{2}$ nanoparticles on the physico-mechanical and ultraviolet light barrier properties of fish gelatin/agar bilayer film. LWT Food Sci. Technol. 2016, 71, 88-95. [CrossRef]

22. Montazer, M.; Pakdel, E.; Moghadam, M.B. Nano titanium dioxide on wool keratin as UV absorber stabilized by butane tetra carboxylic acid (BTCA): A statistical prospect. Fibers Polym. 2010, 11, 967-975. [CrossRef]

23. Wang, S.Y.; Zhu, B.B.; Li, D.Z.; Fu, X.Z.; Shi, L. Preparation and characterization of $\mathrm{TiO}_{2} / \mathrm{SPI}$ composite film. Mater. Lett. 2012, 83, 42-45. [CrossRef]

24. Kadam, D.M.; Thunga, M.; Srinivasan, G.; Wang, S.; Kessler, M.R.; Grewell, D.; Yu, C.; Lamsal, B. Effect of $\mathrm{TiO}_{2}$ nanoparticles on thermo-mechanical properties of cast zein protein films. Food Packag. Shelf Life 2017, 13, 35-43. [CrossRef]

25. He, Q.; Huang, Y.; Lin, B.; Wang, S. A nanocomposite film fabricated with simultaneously extracted protein-polysaccharide from a marine alga and $\mathrm{TiO}_{2}$ nanoparticles. J. Appl. Phycol. 2017, 29, 1541-1552. [CrossRef]

26. He, Q.; Zhang, Y.; Cai, X.; Wang, S. Fabrication of gelatin- $\mathrm{TiO}_{2}$ nanocomposite film and its structural, antibacterial and physical properties. Int. J. Biol. Macromol. 2016, 84, 153-160. [CrossRef]

27. Fan, X.; Chen, K.; He, X.; Li, N.; Huang, J.; Tang, K.; Li, Y.; Wang, F. Nano-TiO 2 /collagen-chitosan porous scaffold for wound repairing. Int. J. Biol. Macromol. 2016, 91, 15-22. [CrossRef]

28. Alizadeh Sani, M.; Ehsani, A.; Hashemi, M. Whey protein isolate/cellulose nanofibre/TiO 2 nanoparticle/rosemary essential oil nanocomposite film: Its effect on microbial and sensory quality of lamb meat and growth of common foodborne pathogenic bacteria during refrigeration. Int. J. Food Microbiol. 2017, 251, 8-14. [CrossRef]

29. Feng, Z.; Li, L.; Wang, Q.; Wu, G.; Liu, C.; Jiang, B.; Xu, J. Effect of antioxidant and antimicrobial coating based on whey protein nanofibrils with $\mathrm{TiO}_{2}$ nanotubes on the quality and shelf life of chilled meat. Int. J. Mol. Sci. 2019, 20, 1184. [CrossRef]

30. Montes-de-Oca-Ávalos, J.M.; Altamura, D.; Jorge, R. Relationship between nano/microstructure and physical properties of $\mathrm{TiO}_{2}$-sodium caseinate composite films. Food Res. Int. 2018, 105, 129-139. [CrossRef]

31. Zolfi, M.; Khodaiyan, F.; Mousavi, M.; Hashemi, M. The improvement of characteristics of biodegradable films made from kefiran-whey protein by nanoparticle incorporation. Carbohydr. Polym. 2014, 109, 118-125. [CrossRef] [PubMed]

32. Zink, J.; Wyrobnik, T.; Prinz, T.; Schmid, M. Physical, chemical and biochemical modifications of protein-based films and coatings: An extensive review. Int. J. Mol. Sci. 2016, 17, 1376. [CrossRef] [PubMed]

33. Böhmer-Maas, B.W.; Martins, L.; Murowaniecki, D.; Zavareze, R.; Carlos, R. Photocatalytic zein-TiO 2 nanofibers as ethylene absorbers for storage of cherry tomatoes. Food Packag. Shelf Life 2020, 24, 100508. [CrossRef] 
34. Li, N.; Fan, X.; Tang, K.; Zheng, X.; Liu, J.; Wang, B. Nanocomposite scaffold with enhanced stability by hydrogen bonds between collagen, polyvinyl pyrrolidone and titanium dioxide. Coll. Surf. B 2016, 140, 287-296. [CrossRef] [PubMed]

35. Pop, O.L.; Pop, C.R.; Dufrechou, M.; Vodnar, D.C.; Socaci, S.A.; Dulf, F.V.; Minervini, F.; Suharoschi, R. Edible films and coatings functionalization by probiotic incorporation: A review. Polymers 2020, 12, 12. [CrossRef]

36. Acquah, C.; Zhang, Y.; Dubé, M.A.; Udenigwe, C.C. Formation and characterization of protein-based films from yellow pea (Pisum sativum) protein isolate and concentrate for edible applications. Curr. Res. Food Sci. 2020, 2, 61-69. [CrossRef]

37. Agudelo-Cuartas, C.; Granda-restrepo, D.; Sobral, P.J.A.; Hernandez, H. Characterization of whey protein-based fi lms incorporated with natamycin and nanoemulsion of $\alpha$-tocopherol. Heliyon 2020, 6, e03809. [CrossRef]

38. Guo, X.; Ren, C.; Zhang, Y.; Cui, H.; Shi, C. Stability of zein-based films and their mechanism of change during storage at different temperatures and relative humidity. J. Food Process. Preserv. 2020, 44, 1-10. [CrossRef]

39. Su, J.; Huang, Z.; Liu, K.; Fu, L.; Liu, H. Mechanical properties, biodegradation and water vapor permeability of blend films of soy protein isolate and poly(vinyl alcohol) compatibilized by glycerol. Polym. Bull. 2007, 921, 913-921. [CrossRef]

40. Wang, N.; Saleh, A.S.M.; Xiao, Z. Effect of protein aggregates on properties and structure of rice bran protein-based film at different pH. J. Food Sci. Technol. 2019, 56, 5116-5127. [CrossRef]

41. Mangavel, C.; Rossignol, N.; Perronnet, A.; Barbot, A.; Gueguen, J. Properties and microstructure of thermo-pressed Wheat gluten films: A comparison with cast films. Biomacromolecules 2004, 5, 1596-1601. [CrossRef] [PubMed]

42. Alexandre, E.M.C.; Lourenço, R.V.; Bittante, A.M.Q.B.; Moraes, I.C.F.; do Amaral Sobral, P.J. Gelatin-based films reinforced with montmorillonite and activated with nanoemulsion of ginger essential oil for food packaging applications. Food Packag. Shelf Life 2016, 10, 87-96. [CrossRef]

43. Dias, J.R.; Baptista-silva, S.; De Oliveira, C.M.T.; Sousa, A.; Oliveira, A.L. In situ crosslinked electrospun gelatin nanofibers for skin regeneration. Eur. Polym. J. 2017, 95, 161-173. [CrossRef]

44. Rouse, J.G.; Van Dyke, M.E. A review of keratin-based biomaterials for biomedical applications. Materials 2010, 3, 999-1014. [CrossRef]

45. Hauzoukim; Swain, S.; Mohanty, B.; Hauzoukim, S.S.; Mohanty, B. Functionality of protein-based edible coating-Review. J. Entomol. Zool. Stud. 2020, 8, 1432-1440.

46. Kanmani, P.; Rhim, J.W. Physicochemical properties of gelatin/silver nanoparticle antimicrobial composite films. Food Chem. 2014, 148, 162-169. [CrossRef]

47. Bang, Y.J.; Shankar, S.; Rhim, J.W. In situ synthesis of multi-functional gelatin/resorcinol/silver nanoparticles composite films. Food Packag. Shelf Life 2019, 22, 100399. [CrossRef]

48. Cano, A.; Andres, M.; Chiralt, A.; González-Martinez, C. Use of tannins to enhance the functional properties of protein based films. Food Hydrocoll. 2020, 100. [CrossRef]

49. Alizadeh-Sani, M.; Moghaddas Kia, E.; Ghasempour, Z.; Ehsani, A. Preparation of active nanocomposite film consisting of sodium caseinate, $\mathrm{ZnO}$ nanoparticles and rosemary essential oil for food packaging applications. J. Polym. Environ. 2020. [CrossRef]

50. Azevedo, V.M.; Dias, M.V.; de Siqueira Elias, H.H.; Fukushima, K.L.; Silva, E.K.; de Deus Souza Carneiro, J.; de Fátima Ferreira Soares, N.; Borges, S.V. Effect of whey protein isolate films incorporated with montmorillonite and citric acid on the preservation of fresh-cut apples. Food Res. Int. 2018, 107, 306-313. [CrossRef]

51. Pintado, C.M.B.S.; Ferreira, M.A.S.S.; Sousa, I. Properties of whey protein-based films containing organic acids and nisin to control Listeria Monocytogenes. J. Food Prot. 2009, 72, 1891-1896. [CrossRef] [PubMed]

52. Pluta-Kubica, A.; Jamróz, E.; Kawecka, A.; Juszczak, L.; Krzyściak, P. Active edible furcellaran/whey protein films with yerba mate and white tea extracts: Preparation, characterization and its application to fresh soft rennet-curd cheese. Int. J. Biol. Macromol. 2020, 155, 1307-1316. [CrossRef] [PubMed]

53. Arfat, Y.A.; Benjakul, S.; Prodpran, T.; Sumpavapol, P.; Songtipya, P. Physico-mechanical characterization and antimicrobial properties of fish protein isolate/fish skin gelatin-zinc oxide $(\mathrm{ZnO})$ nanocomposite films. Food Bioprocess Technol. 2016, 9, 101-112. [CrossRef] 
54. Salama, A. Soy protein acid hydrolysate/silica hybrid material as novel adsorbent for methylene blue. Compos. Commun. 2019, 12, 101-105. [CrossRef]

55. Asadzadeh, F.; Pirsa, S. Specific removal of nitrite from Lake Urmia sediments by biohydrogel based on isolated soy protein/tragacanth/mesoporous silica nanoparticles/lycopene. Glob. Chall. 2020, 2000061, 1-12. [CrossRef]

56. Hou, C.; Xu, Z.; Qiu, W.; Wu, R.; Wang, Y.; Xu, Q.; Liu, X.Y. A Biodegradable and stretchable protein-based sensor as artificial electronic skin for human motion detection. Small 2019, 1805084, 1-8. [CrossRef]

57. You, R.; Zhang, J.; Gu, S.; Zhou, Y.; Li, X.; Ye, D.; Xu, W. Regenerated egg white/silk fibroin composite films for biomedical applications. Mater. Sci. Eng. C 2017, 79, 430-435. [CrossRef]

58. Topoglidis, E.; Cass, A.E.G.; Gilardi, G.; Sadeghi, S.; Beaumont, N.; Durrant, J.R. Protein adsorption on nanocrystalline $\mathrm{TiO}_{2}$ films: An immobilization strategy for bioanalytical devices. Anal. Chem. 1998, 70, 5111-5113. [CrossRef]

59. Ranjan, S.; Dasgupta, N.; Sudandiradoss, C.; Ramalingam, C.; Kumar, A. Titanium dioxide nanoparticle-protein interaction explained by docking approach. Int. J. Nanomed. 2018, 13, 47-50. [CrossRef]

60. Hashim, J.; Looney, L.; Hashmi, M.S.J. Metal matrix composites: Production by the stir casting method. J. Mater. Process. Technol. 1999, 92, 1-7. [CrossRef]

61. Asri, R.I.M.; Harun, W.S.W.; Hassan, M.A.; Ghani, S.A.C.; Buyong, Z. A review of hydroxyapatite-based coating techniques: Sol-gel and electrochemical depositions on biocompatible metals. J. Mech. Behav. Biomed. Mater. 2016, 57, 95-108. [CrossRef] [PubMed]

62. Jilani, A.; Abdel-wahab, M.S.; Hammad, A.H. Advance deposition techniques for thin film and coating. In Modern Technologies for Creating the Thin-Film Systems and Coatings; BoD-Books on Demand: Norderstedt, Germany, 2017; pp. 137-149.

63. Tang, X.; Yan, X. Dip-coating for fibrous materials: Mechanism, methods and applications. J. Sol-Gel Sci. Technol. 2017, 81, 378-404. [CrossRef]

64. Andres, C.M.; Kotov, N.A. Inkjet deposition of layer-by-layer assembled films. J. Am. Chem. Soc. 2010, 132, 14496-14502. [CrossRef] [PubMed]

65. Richardson, J.J.; Björnmalm, M.; Caruso, F. Technology-driven layer-by-layer assembly of nanofilms. Science 2015, 348, 411-422. [CrossRef]

66. Baudron, V.; Gurikov, P.; Smirnova, I.; Whitehouse, S. Porous starch materials via supercritical-and freeze-drying. Gels 2019, 5, 12. [CrossRef]

67. Liew, K.B.; Odeniyi, M.A.; Peh, K.K. Application of freeze-drying technology in manufacturing orally disintegrating films. Pharm. Dev. Technol. 2016, 21, 346-353. [CrossRef]

68. Matysiak, W.; Tanski, T.; Smok, W. Electrospinning as a versatile method of composite thin films fabrication for selected applications. Solid State Phenom. 2019, 293, 35-49. [CrossRef]

69. Amrollahi, P.; Krasinki, J.S.; Vaidyanathan, R.; Tayebi, L.; Vashaee, D. Electrophoretic deposition (EPD): Fundamentals and applications from nano- to micro-scale structures. Handb. Nanoelectrochemistry 2015. [CrossRef]

70. Emregul, E.; Kocabay, O.; Derkus, B.; Yumak, T.; Emregul, K.C.; Sinag, A.; Polat, K. A novel carboxymethylcellulose-gelatin-titanium dioxide-superoxide dismutase biosensor; electrochemical properties of carboxymethylcellulose-gelatin-titanium dioxide-superoxide dismutase. Bioelectrochemistry 2013, 90, 8-17. [CrossRef]

71. Ferreira, R.; Padilla, R.; Urkasemsin, G.; Yoon, K.; Goeckner, K.; Hu, W.S.; Ko, C.C. Titanium-enriched hydroxyapatite-gelatin scaffolds with osteogenically differentiated progenitor cell aggregates for calvaria bone regeneration. Tissue Eng. Part A 2013, 19, 1803-1816. [CrossRef]

72. Gautam, R.K.; Kakatkar, A.S.; Karani, M.N. Development of protein-based biodegradable films from fish processing waste. Int. J. Curr. Microbiol. Appl. Sci. 2016, 5, 878-888. [CrossRef]

73. Nikpasand, A.; Parvizi, M.R. Evaluation of the Effect of titatnium dioxide nanoparticles/gelatin composite on infected skin wound healing; An animal model study. Bull. Emerg. Trauma 2019, 7, 366-372. [CrossRef] [PubMed]

74. Azizi-Lalabadi, M.; Alizadeh-Sani, M.; Divband, B.; Ehsani, A.; Julian, D. Nanocomposite films consisting of functional nanoparticles $\left(\mathrm{TiO}_{2}\right.$ and $\mathrm{ZnO}$ ) embedded in $4 \mathrm{~A}$-Zeolite and mixed polymer matrices (gelatin and polyvinyl alcohol). Food Res. Int. 2020, 137, 109716. [CrossRef] [PubMed] 
75. Azizi-Lalabadi, M.; Ehsani, A.; Ghanbarzadeh, B.; Divband, B. Polyvinyl alcohol/gelatin nanocomposite containing $\mathrm{ZnO}, \mathrm{TiO}_{2}$ or $\mathrm{ZnO} / \mathrm{TiO}_{2}$ nanoparticles doped on $4 \mathrm{~A}$-zeolite: Microbial and sensory qualities of packaged white shrimp during refrigeration. Int. J. Food Microbiol. 2020, 312, 108375. [CrossRef]

76. Nassiri, R.; Mohammady Nafchi, A. Antimicrobial and barrier properties of bovine gelatin films reinforced by nano $\mathrm{TiO}_{2}$. J. Chem. Health Risks 2013, 3, 21-28.

77. Pirsa, S.; Farshchi, E.; Roufegarinejad, L. Antioxidant/antimicrobial film based on carboxymethyl cellulose/gelatin/ $\mathrm{TiO}_{2}-\mathrm{Ag}$ nanocomposite. J. Polym. Environ. 2020. [CrossRef]

78. Vejdan, A.; Ojagh, S.M.; Abdollahi, M. Effect of gelatin/agar bilayer film incorporated with $\mathrm{TiO}_{2}$ nanoparticles as a UV absorbent on fish oil photooxidation. Int. J. Food Sci. Technol. 2017, 52, 1862-1868. [CrossRef]

79. Urruela-Barrios, R.; Ramírez-Cedillo, E.; de León, A.D.; Alvarez, A.J.; Ortega-Lara, W. Alginate/gelatin hydrogels reinforced with $\mathrm{TiO}_{2}$ and $\beta$-TCP fabricated by microextrusion-based printing for tissue regeneration. Polymers 2019, 11, 457. [CrossRef]

80. Lai, M.; Jin, Z.; Qiao, W. Surface immobilization of gelatin onto $\mathrm{TiO}_{2}$ nanotubes to modulate osteoblast behavior. Coll. Surf. B 2017, 159, 743-749. [CrossRef]

81. Yan, Y.; Zhang, X.; Mao, H.; Huang, Y.; Ding, Q.; Pang, X. Hydroxyapatite/gelatin functionalized graphene oxide composite coatings deposited on $\mathrm{TiO}_{2}$ nanotube by electrochemical deposition for biomedical applications. Appl. Surf. Sci. 2015, 329, 76-82. [CrossRef]

82. Hosokawa, A.; Kato, Y.; Terada, K. Imprinting on empty hard gelatin capsule shells containing titanium dioxide by application of the UV laser printing technique. Drug Dev. Ind. Pharm. 2014, 9045, 1047-1053. [CrossRef] [PubMed]

83. Hayajneh, M.T.; Almomani, M.; Al-daraghmeh, M. Enhancement the corrosion resistance of AISI-304 stainless steel by nanocomposite gelatin-titanium dioxide coatings. Manuf. Technol. 2019, 19, 759-766. [CrossRef]

84. Liu, B.; Xiao, J.; Xu, L.; Yao, Y.; Costa, B.F.O.; Domingos, V.F.; Ribeiro, E.S.; Shi, F.N.; Zhou, K.; Su, J.; et al. Gelatin-assisted sol-gel derived $\mathrm{TiO}_{2}$ microspheres for hydrogen storage. Int. J. Hydrog. Energy 2015, 40, 4945-4950. [CrossRef]

85. Jao, D.; Xue, Y.; Medina, J.; Hu, X. Protein-based drug-delivery materials. Materials 2017, 10, 517. [CrossRef] [PubMed]

86. Alizadeh-Sani, M.; Khezerlou, A.; Ehsani, A. Fabrication and characterization of the bionanocomposite film based on whey protein biopolymer loaded with $\mathrm{TiO}_{2}$ nanoparticles, cellulose nanofibers and rosemary essential oil. Ind. Crops Prod. 2018, 124, 300-315. [CrossRef]

87. Zhou, J.J.; Wang, S.Y.; Gunasekaran, S. Preparation and characterization of whey protein film incorporated with $\mathrm{TiO}_{2}$ nanoparticles. J. Food Sci. 2009, 74. [CrossRef]

88. Alizadeh-Sani, M.; Mohammadian, E.; Julian, D. Eco-friendly active packaging consisting of nanostructured biopolymer matrix reinforced with $\mathrm{TiO}_{2}$ and essential oil: Application for preservation of refrigerated meat. Food Chem. 2020, 322, 126782. [CrossRef]

89. Zhang, W.; Chen, J.; Chen, Y.; Xia, W.; Xiong, Y.L.; Wang, H. Enhanced physicochemical properties of chitosan/whey protein isolate composite film by sodium laurate-modified $\mathrm{TiO}_{2}$ nanoparticles. Carbohydr. Polym. 2016, 138, 59-65. [CrossRef]

90. Zolfi, M.; Khodaiyan, F.; Mousavi, M.; Hashemi, M. Development and characterization of the kefiran-whey protein isolate- $\mathrm{TiO}_{2}$ nanocomposite films. Int. J. Biol. Macromol. 2014, 65, 340-345. [CrossRef] [PubMed]

91. Gohargani, M.; Lashkari, H.; Shirazinejad, A. Study on biodegradable chitosan-whey protein-based film containing bionanocomposite $\mathrm{TiO}_{2}$ and Zataria multiflora essential oil. J. Food Qual. 2020, 8844167. [CrossRef]

92. Ortelli, S.; Malucelli, G.; Cuttica, F.; Blosi, M.; Zanoni, I.; Luisa, A. Coatings made of proteins adsorbed on $\mathrm{TiO}_{2}$ nanoparticles: A new flame retardant approach for cotton fabrics. Cellulose 2018, 25, 2739-2749. [CrossRef]

93. Córdoba, L.C.; Hélary, C.; Montemor, F.; Coradin, T. Bi-layered silane- $\mathrm{TiO}_{2} /$ collagen coating to control biodegradation and biointegration of Mg alloys. Mater. Sci. Eng. C 2019, 94, 126-138. [CrossRef] [PubMed]

94. Truc, N.T.; Minh, H.H.; Khanh, L.L.; Thuy, V.M.; Van Toi, V.; Van Man, T.; Nam, H.C.N.; Quyen, T.N.; Hiep, N.T. Modification of type I collagen on $\mathrm{TiO}_{2}$ surface using electrochemical deposition. Surf. Coat. Technol. 2018, 344, 664-672. [CrossRef]

95. Nojiri, T.; Chen, C.Y.; Kim, D.M.; Da Silva, J.; Lee, C.; Maeno, M.; Mcclelland, A.A.; Tse, B.; Nagai, S.I.; Hatakeyama, W.; et al. Establishment of perpendicular protrusion of type $\mathrm{I}$ collagen on $\mathrm{TiO}_{2}$ nanotube surface as a priming site of peri-implant connective fibers. J. Nanobiotechnol. 2019, 17, 34. [CrossRef] 
96. Bishal, A.K.; Sukotjo, C.; Jokisaari, J.R.; Klie, R.F.; Takoudis, C.G. Enhanced bioactivity of collagen fiber functionalized with room temperature atomic layer deposited titania. ACS Appl. Mater. Interfaces 2018, 10, 34443-34454. [CrossRef]

97. Vedhanayagam, M.; Anandasadagopan, S.; Nair, B.U.; Sreeram, K.J. Polymethyl methacrylate (PMMA) grafted collagen scaffold reinforced by $\mathrm{PdO}-\mathrm{TiO}_{2}$ nanocomposites. Mater. Sci. Eng. C 2019, 110378. [CrossRef]

98. Erciyes, A.; Ocak, B. Physico-mechanical, thermal, and ultraviolet light barrier properties of collagen hydrolysate films from leather solid wastes incorporated with nano $\mathrm{TiO}_{2}$. Polym. Compos. 2019, 40, 4716-4725. [CrossRef]

99. Luo, T.; Wan, X.J.; Jiang, S.X.; Zhang, L.Y.; Hong, Z.Q.; Liu, J. Preparation and photocatalytic performance of fibrous $\mathrm{Tb}^{3+}$-doped $\mathrm{TiO}_{2}$ using collagen fiber as template. Appl. Phys. A Mater. Sci. Process. 2018, 124, 304. [CrossRef]

100. Chen, H.; Liu, H.; Guo, Y.; Wang, B.; Wei, Y.; Zhang, Y.; Wu, H. Hierarchically ordered mesoporous $\mathrm{TiO}_{2}$ nanofiber bundles derived from natural collagen fibers for lithium and sodium storage. J. Alloys Compd. 2017, 731, 844-852. [CrossRef]

101. Liu, Y.; Xu, L.; Li, R.; Zhang, H.; Cao, W.; Li, T.; Zhang, Y. Preparation and characterization of soy protein isolate films incorporating modified nano-TiO 2 . Int. J. Food Eng. 2019, 15, 1-13. [CrossRef]

102. Malathi, A.N.; Kumar, N.; Nidoni, U.; Hiregoudar, S. Development of soy protein isolate films reinforced with titanium dioxide nanoparticles. Int. J. Agric. Environ. Biotechnol. 2017, 10, 141. [CrossRef]

103. Burgos, N.; Valdés, A.; Jiménez, A. Valorization of agricultural wastes for the production of protein-based biopolymers. J. Renew. Mater. 2016, 4, 165-177. [CrossRef]

104. Calva-Estrada, S.J.; Jiménez-Fernández, M.; Lugo-Cervantes, E. Protein-based films: Advances in the development of biomaterials applicable to food packaging. Food Eng. Rev. 2019, 11, 78-92. [CrossRef]

105. Zhang, Y.; Lin, S.; Lin, B.; Wang, W.; Wang, S. Studies on fresh-keeping strawberry using TiCVSPI composite film. J. Chin. Inst. Food Sci. Technol. 2015, 15, 120-125. [CrossRef]

106. Hoseiniyan, F.; Amiri, S.; Rezazadeh Bari, M.; Rezazad Bari, L.; Dodangeh, S. Effect of soy protein isolate and $\mathrm{TiO}_{2}$ edible coating on quality and shelf-life of grapes varieties Hosseini and Ghezel Ozom. FSCT 2020, $17,29-41$.

107. Vasconcellos, F.C.S.; Woiciechowski, A.L.; Soccol, V.T.; Mantovani, D.; Soccol, C.R. Antimicrobial and antioxidant properties of $\beta$-conglycinin and glycinin from soy protein isolate. Int. J. Curr. Microbiol. Appl. Sci. 2014, 3, 144-157.

108. Calza, P.; Zacchigna, D.; Laurenti, E. Degradation of orange dyes and carbamazepine by soybean peroxidase immobilized on silica monoliths and titanium dioxide. Environ. Sci. Pollut. Res. 2016, 23, 23742-23749. [CrossRef]

109. Amjadi, S.; Almasi, H.; Ghorbani, M.; Ramazani, S. Preparation and characterization of $\mathrm{TiO}_{2} \mathrm{NPs}_{\text {and }}$ betanin loaded zein/sodium alginate nanofibers. Food Packag. Shelf Life 2020, 24, 100504. [CrossRef]

110. Wu, S.; Chen, X.; Yi, M.; Ge, J.; Yin, G.; Li, X. Improving thermal, mechanical, and barrier properties of feather keratin/polyvinyl alcohol/Tris (hydroxymethyl) aminomethane nanocomposite films by incorporating sodium montmorillonite and $\mathrm{TiO}_{2}$. Nanomaterials 2019, 9, 298. [CrossRef]

111. Villanueva, M.E.; Puca, M.; Pérez Bravo, J.; Bafico, J.; Campo Dall Orto, V.; Copello, G.J. Dual adsorbentphotocatalytic keratin- $\mathrm{TiO}_{2}$ nanocomposite for trimethoprim removal from wastewater. New J. Chem. 2020, 44, 10964-10972. [CrossRef]

112. Siriorn, I.N.A.; Jatuphorn, W. Investigation of morphology and photocatalytic activities of electrospun chicken feather keratin/PLA/TiO $2 /$ clay nanofibers. E3S Web Conf. 2020, 141, 01003. [CrossRef]

113. Babitha, S.; Korrapati, P.S. $\mathrm{TiO}_{2}$ immobilized zein microspheres: A biocompatible adsorbent for effective dye decolourisation. RSC Adv. 2015, 5, 26475-26481. [CrossRef]

114. Johari, N.; Hosseini, H.R.M.; Samadikuchaksaraei, A. Novel fluoridated silk fibroin/ $/ \mathrm{TiO}_{2}$ nanocomposite scaffolds for bone tissue engineering. Mater. Sci. Eng. C 2017, 82, 265-276. [CrossRef] [PubMed]

115. Mehrabani, M.G.; Karimian, R.; Rakhshaei, R.; Pakdel, F.; Eslami, H.; Fakhrzadeh, V.; Rahimi, M.; Salehi, R.; Kafil, H.S. Chitin/silk fibroin/ $\mathrm{TiO}_{2}$ bio-nanocomposite as a biocompatible wound dressing bandage with strong antimicrobial activity. Int. J. Biol. Macromol. 2018, 116, 966-976. [CrossRef] 
116. Kazek-Kesik, A.; Peitryga, K.; Basiaga, M.; Blacha-Grzechnik, A.; Dercz, G.; Kalemba-Rec, I.; Pamula, E.; Simka, W. Lactoferrin and collagen type I as components of composite formed. Surf. Coat. Technol. 2017, 328, 1-12. [CrossRef]

117. Feng, X.; Guo, Y.; Chen, J.; Zhang, J. Nano-TiO 2 induced secondary structural transition of silk fibroin studied by two-dimensional Fourier-transform infrared correlation spectroscopy and Raman spectroscopy. J. Biomater. Sci. 2012, 18, 1443-1456. [CrossRef]

118. Hu, M.; Lin, D.; Shang, Y.; Hu, Y.; Lu, W.; Huang, X.; Ning, K.; Chen, Y.; Wang, Y. CO2-induced pH reduction increases physiological toxicity of nano- $\mathrm{TiO}_{2}$ in the mussel Mytilus coruscus. Sci. Rep. 2017, 7, 1-11. [CrossRef]

119. Chen, Z.; Han, S.; Zheng, P.; Zhou, D.; Zhou, S.; Jia, G. Effect of oral exposure to titanium dioxide nanoparticles on lipid metabolism in Sprague-Dawley rats. Nanoscale 2020, 12, 5973-5986. [CrossRef]

120. Runa, S.; Khanal, D.; Kemp, M.L.; Payne, C.K. $\mathrm{TiO}_{2}$ nanoparticles alter the expression of peroxiredoxin antioxidant genes. J. Phys. Chem. C 2016, 120, 20736-20742. [CrossRef]

121. Tucci, P.; Porta, G.; Agostini, M.; Dinsdale, D.; Iavicoli, I.; Cain, K.; Finazzi-Agró, A.; Melino, G.; Willis, A. Metabolic effects of $\mathrm{TiO}_{2}$ nanoparticles, a common component of sunscreens and cosmetics, on human keratinocytes. Cell Death Dis. 2013, 4, 1-11. [CrossRef] [PubMed]

122. Gheshlaghi, Z.N.; Riazi, G.H.; Ahmadian, S.; Ghafari, M.; Mahinpour, R. Toxicity and interaction of titanium dioxide nanoparticles with microtubule protein. Acta Biochim. Biophys. Sin. 2008, 40,777-782. [CrossRef] [PubMed]

123. $\mathrm{Xu}, \mathrm{Z}$;; Grassian, V.H. Bovine serum albumin adsorption on $\mathrm{TiO}_{2}$ nanoparticle surfaces: Effects of $\mathrm{pH}$ and co-adsorption of phosphate on protein-surface interactions and protein structure. J. Phys. Chem. C 2017, 121, 21763-21771. [CrossRef]

124. Sharif, H.A.; Rasha, A.A.E.; Ramia, Z.A.B. Titanium dioxide content in foodstuffs from the Jordanian market: Spectrophotometric evaluation of $\mathrm{TiO}_{2}$ nanoparticles. Int. Food Res. J. 2015, 22, 1024-1029.

125. Wang, Y.Q.; Zhang, H.M.; Wang, R.H. Investigation of the interaction between colloidal $\mathrm{TiO}_{2}$ and bovine hemoglobin using spectral methods. Colloids Surfaces B Biointerfaces. 2008, 65, 190-196. [CrossRef] [PubMed]

Publisher's Note: MDPI stays neutral with regard to jurisdictional claims in published maps and institutional affiliations.

(C) 2020 by the authors. Licensee MDPI, Basel, Switzerland. This article is an open access article distributed under the terms and conditions of the Creative Commons Attribution (CC BY) license (http://creativecommons.org/licenses/by/4.0/). 